\title{
Are morphological criteria sufficient for the identification of circulating tumor cells in renal cancer?
}

Amin El-Heliebi ${ }^{1}$, Thomas Kroneis ${ }^{1}$, Evelyn Zöhrer ${ }^{1}$, Johannes Haybaeck², Katja Fischereder ${ }^{3}$, Karin Kampel-Kettner ${ }^{3}$, Richard Zigeuner ${ }^{3}$, Hannelore Pock ${ }^{4}$, Regina Riedl ${ }^{5}$, Rudolf Stauber ${ }^{4}$, Jochen Bernd Geigl ${ }^{6}$, Berthold Huppertz ${ }^{1}$, Peter Sedlmayr ${ }^{1 \dagger}$ and Carolin Lackner ${ }^{2^{*}+}$

\begin{abstract}
Background: Single circulating tumor cells (CTCS) or circulating tumor microemboli (CTMs) are potential biomarkers of renal cell cancer (RCC), however studies of CTCS/CTMs in RCC are limited. In this pilot study we aimed to evaluate a novel blood filtration technique suited for cytomorphological classification, immunocytochemical and molecular characterization of filtered, so called circulating non-hematologic cells (CNHCs) - putative CTCS/CTMs - in patients with RCC.

Methods: Blood of 40 patients with renal tumors was subjected to ScreenCell ${ }^{\oplus}$ filtration. CNHCs were classified according to cytomorphological criteria. Immunocytochemical analysis was performed with antibodies against CD45, CD31 and carbonic anhydrase IX (CAIX, a RCC marker). DNA of selected CNHCs and respective primary tumors was analysed by array-CGH.
\end{abstract}

Results: CNHC-clusters with malignant or uncertain malignant cytomorphological features - putative CTMs - were negative for CD45, positive for CD31, while only $6 \%$ were CAIX positive. Array-CGH revealed that $83 \%$ of malignant and uncertain malignant cells did represent with a balanced genome whereas $17 \%$ presented genomic DNA imbalances which did not match the aberrations of the primary tumors. Putative single CTCs were negative for CD45, 33\% were positive for CD31 and 56\% were positive for CAIX.

Conclusions: The majority of CNHC-clusters, putative CTMs, retrieved by ScreenCell ${ }^{\circledast}$ filtration may be of endothelial origin. Morphological criteria seem to be insufficient to distinguish malignant from non-malignant cells in renal cancer.

Keywords: Circulating tumor cells, Circulating tumor microemboli, Renal cancer, ScreenCell ${ }^{\circledast}$, Array comparative genomic hybridization (array-CGH), Circulating endothelial cells

\section{Background}

Hematogenous dissemination of single tumor cells (circulating tumor cells, CTCs) or tumor microemboli (circulating tumor microemboli, CTM) is an important mechanism involved in the formation of metastases, the major cause of cancer related death [1]. Results of numerous studies

\footnotetext{
* Correspondence: karoline.lackner@medunigraz.at

${ }^{\dagger}$ Equal contributors

${ }^{2}$ Institute of Pathology, Medical University of Graz, Auenbruggerplatz 25, 8036 Graz, Austria

Full list of author information is available at the end of the article
}

indicate the prognostic value of CTC detection and enumeration in many human cancers. This has been confirmed in recent meta analyses for breast [2] and colorectal cancer [3]. Besides enumeration, results of the molecular analyses of CTCs may be used to predict treatment response [4]. Investigation of CTCs may hold great promise to inform individualized treatment strategies as well as to increase the knowledge about the metastatic process in itself. Renal cell cancer (RCC) is the most frequent solid lesion of the kidney and accounts for $3 \%$ of all cancer cases worldwide. Approximately $20 \%$ of primary localized RCC will develop metastatic disease

\section{Biomed Central}


negatively impacting on patient survival [5]. Therapeutic options are limited by resistance of RCC to chemotherapy and radiation, but have recently been improved by the advent of targeted therapies [6,7]. As in other malignancies, CTCs may also be valuable prognostic and predictive biomarkers of renal cancers, however studies of CTCs in RCC are limited (reviewed in [8]).

Several techniques for the detection and enumeration of CTCs have been developed during the last years and the list is continuously growing. Many methods use epithelial antigenic properties of cancer cells to detect and isolate them from blood by immunomagnetic or microfluidic based enrichment methods (reviewed in [9]). However, many of these detection systems are not commercially available and/or economically accessible. Another obstacle is the epithelial antigen-based detection of CTCs. Epithelial to mesenchymal transition (EMT) is believed to represent an integral component of the metastatic process in which cancer cells down regulate the expression of epithelial markers in favour of mesenchymal markers, a process linked to the stemness of cancer cells and increased chemoresistance [10-13]. Hence such CTCs may therefore escape detection. Recently filtration based size exclusion technologies have been developed [14,15] which allow for antigen-independent isolation of CTCs from blood based on their larger size and cytomorphological features in comparison to hematological cells [16]. Some of these methods like the ScreenCell $^{\odot}$ filtration system are commercially available. CTCs can be isolated from diluted blood in a single step using a translucent polycarbonate membrane. Following filtration they can be further analysed by light microscopy and immunocytochemistry [16-21] but molecular data on putative CTCs/CTMs are limited [21-23].

Using the ScreenCell ${ }^{\oplus}$ filtration system and array-CGH technology we aimed to evaluate if morphological criteria [17] are sufficient to identify CTCs/CTMs in blood of renal cancer patients. Here we report for the first time chromosomal analysis of circulating non-hematological cell clusters cytomorphologically resembling CTMs by array-CGH.

\section{Methods}

\section{Ethical statement}

The study was approved by the ethics committee of the Medical University of Graz (reference EK: 19-239 ex 07/08). Written informed consent was obtained from all patients. The human iliac arterial endothelial primary cells (HIAEC) (generously provided by Dr. I. Lang-Olip, Medical University of Graz, Austria) derived from an organ donor. Ethical approval was granted by the ethics committee of the Medical University of Graz (reference EK: 19-293 ex 07/08). The ethics committee waived the need for written informed consent as the donor fulfilled presumed-consent according to Austrian Hospitals Act.

\section{Patients and tissues}

Thirty consecutive patients diagnosed of renal cell carcinomas (25 clear cell and 5 papillary carcinomas) and for control purposes 10 patients with benign renal tumors (1 renal cyst, 2 angiomyolipoma, 6 oncocytoma and 1 cystic nephroma) diagnosed between 2010 and 2011 were included in the study. All patients underwent surgical resection of the tumor. Clinical and histopathological parameters of the study cohort are compiled in Table 1. Blood samples from 20 healthy volunteers were used as age and sex matched negative controls. Formaldehyde ( $4 \% \mathrm{~m} / \mathrm{V}$ buffered solution)-fixed and paraffin-embedded (FFPE) tumor specimens were retrieved from the BioBank of the Medical University of Graz, Austria. In $40 \%$ of the cases tumor tissue snap frozen in liquid nitrogen was available. All cancer patients were classified according to the TNM Classification of Malignant Tumors of the International Union

\section{Table 1 Clinical and histopathological characteristics of} the study cohort

\begin{tabular}{|c|c|}
\hline Parameter & Patients, n; (\%) \\
\hline Age, median; (range) & 68; (30-83) \\
\hline Men & $28 ;(70)$ \\
\hline Women & $12 ;(30)$ \\
\hline Benign tumors & $10 ;(25)$ \\
\hline Renal cysts & $1 ;(2.5)$ \\
\hline Angiomyolipoma & $2 ;(5)$ \\
\hline Oncocytoma & $6 ;(15)$ \\
\hline Cystic Nephroma & $1 ;(2.5)$ \\
\hline Tumor size (cm), median; (range) & $2.5 ;(1.0-6.0)$ \\
\hline Malignant tumors & $30 ;(75)$ \\
\hline Clear cell RCC & $25 ;(62.5)$ \\
\hline Papillary RCC & $5 ;(12.5)$ \\
\hline Tumor size (cm), median; (range) & $4 ;(1.3-12.0)$ \\
\hline \multicolumn{2}{|l|}{ Tumor differentiation } \\
\hline G1 & $6 ;(20)$ \\
\hline G2 & $16 ;(53.3)$ \\
\hline G3 & $8 ;(26.7)$ \\
\hline $\begin{array}{l}\text { Venous invasion (in cases of } \\
\text { potentially invasive tumors) }\end{array}$ & $6 ;(16)$ \\
\hline $\begin{array}{l}\text { Distant metastasis (in cases of } \\
\text { potentially invasive tumors) }\end{array}$ & $1 ;(3)$ \\
\hline \multicolumn{2}{|l|}{ Type of surgical intervention } \\
\hline Open partial nephrectomy & $24 ;(60)$ \\
\hline Open nephrectomy & $6 ;(15)$ \\
\hline Transperitoneal nephrectomy & $4 ;(10)$ \\
\hline Laparoscopic nephrectomy & $3 ;(7.5)$ \\
\hline Laparoscopic partial nephrectomy & $2 ;(5)$ \\
\hline CT targeted biopsy & $1 ;(2.5)$ \\
\hline
\end{tabular}


Against Cancer (UICC) [24]. Seventeen (57\%) RCC tumors were staged $\mathrm{T} 1 \mathrm{a}$, five $(17 \%)$ were classified as T1b, four $(13 \%)$ as T2a and four (13\%) as T3a, respectively. Six (20\%) of RCC tumors were graded G1, 16 (53\%) G2 and 8 (27\%) G3, respectively. In the tumors of six patients (16\%) venous invasion was found.

\section{Blood sample collection}

From each patient a total of 4 blood samples were collected in $2 \times 6 \mathrm{ml}$ EDTA tubes (Greiner Bio-One, Kremsmünster, Austria) from a peripheral vein. The first sample was drawn one day prior to surgery (time point A), the next time points of collection were once, during surgery shortly after removal of the tumor (time point $\mathrm{B}$ ), one day after surgery (time point $\mathrm{C}$ ) and eight days after surgery (time point $\mathrm{D}$ ).

\section{DNA extraction of primary tumor tissue}

Genomic DNA was extracted from snap frozen tumor tissue or if not available, from FFPE tumor tissue using the QIAamp DNA Mini Kit (Qiagen, Hilden, Germany) as described by the manufacturer. DNA quantity and quality was assessed by Nanodrop measurement (Thermo Fisher Scientific, Waltham, USA) and DNA fragmentation was analysed by agarose gel electrophoresis [25].

\section{Cell lines and evaluation of the sensitivity of the ScreenCell ${ }^{\circledR}$ filtration device}

The female renal cell adenocarcinoma cell line 769-P was purchased from ATCC (Manassas, USA) and cultivated in RPMI supplemented with $10 \%$ fetal calf serum, $1 \mathrm{mM}$ sodium pyruvate, $100 \mathrm{U} / \mathrm{ml}$ penicillin and $100 \mu \mathrm{g} / \mathrm{ml}$ streptomycin (all cell culture supplies from Gibco, Invitrogen, Carlsbad, USA). The human iliac arterial endothelial primary cells (HIAEC) (generously provided by Dr. I. Lang-Olip, Medical University of Graz, Austria) were grown in endothelial growth medium-2 (EGM-2) (Lonza, Walkersville, USA).

The sensitivity of the ScreenCell $^{\odot}$ filtration method was evaluated in nine independent experiments by spiking cultured renal cell cancer cells (769-P cell line) into blood samples from a healthy volunteer. Confluent 769-P cells were harvested by trypsinization using 0.05\% TrypsinEDTA buffer (PAA, Pasching, Austria). Then defined numbers (three batches of 2, 10 and 50 individual cells) were picked under an inverted microscope (Zeiss Axiovert M 200, Munich, Germany) using a micromanipulator (MMJ, Zeiss; CellTram vario, Eppendorf, Hamburg, Germany) equipped with microcapillaries (inner diameter of $20 \mu \mathrm{m}$ ) (TransferTip, Eppendorf). Picked cells were directly transferred into the blood sample which was then processed by filtration and hematoxylin staining. Cells were enumerated and recovery rates were calculated.

\section{ScreenCell ${ }^{\circledR}$ filtration}

All blood samples were processed within 4 hours after collection of blood as recommended by the manufacturer (ScreenCell ${ }^{\oplus}$, Paris, France). Filtration was carried out as previously described [15] with minor modifications. Briefly, blood was diluted 8 fold with red blood cell lysis buffer (ScreenCell ${ }^{\circ}$, Paris, France) and incubated for $10 \mathrm{~min}$ at RT, with gentle agitation after 3 and 6 min. Per patient and time point 4 filtrations, each corresponding to the processing of $2 \mathrm{ml}$ of whole blood were performed using vacutainer tubes as described by the manufacturer. Thereafter the filters were rinsed with $2 \mathrm{ml}$ of sterile phosphate-buffered saline (PBS $\mathrm{pH}$ 7.4) and collected from the device. The filters were counterstained with hematoxylin (Merck, Darmstadt, Germany) for $5 \mathrm{~min}$ and blued for a few seconds with $\mathrm{NH}_{3}-\mathrm{H}_{2} \mathrm{O}(0.06 \% \mathrm{~m} / \mathrm{V})$, washed in distilled water, air dried and mounted on a glass slide for evaluation by light microscopy. Of 14 selected cases (11 patients with RCC, 1 with oncocytoma, and 2 cases with benign tumors) three of the four filters remained unstained and were stored at $-20^{\circ} \mathrm{C}$ until further immunocytochemical analysis.

\section{Cytomorphological analyses of filtered cells}

Stained filters were analysed by light microscopy by a board certified cytopathologist (CL) using the cytomorphological criteria recently issued by a panel of ten expert cytopathologists for the classification of circulating nonhematological cells $(\mathrm{CNHC})$ filtered from blood using the method "isolation by size of epithelial tumor cells" (ISET) as published by Hofman et al. [17]. This filtration technology is based on comparable principles for isolation of CTCs/CTMs from blood, i.e. size exclusion by filtration through a translucent polycarbonate membrane filter with $8 \mu \mathrm{m}$ pore size using vacuum suction, as the ScreenCell $^{\circ}$ system. Therefore cytomorphological criteria established with ISET filtration may also be used to evaluate filtered cells on ScreenCell $^{\odot}$ filters. The proposed criteria by Hofman have also been applied to renal cell carcinoma in one study [17]. According to these criteria filtered cells $>8 \mu \mathrm{m}$ are classified as $\mathrm{CNHC}$ with malignant (CNHC-MF), uncertain malignant (CNHC-UMF) and benign features (CNHC-BF) (Figure 1A-F).

$\mathrm{CNHC}$ occurring as cellular aggregates (clusters) were classified as CNHC-MF (Figure 1A) if at least four of the following criteria were present:

$\circ$ Anisonucleosis (ratio $>0.5$ )

- Nuclei larger than 3 times the calibrated $8 \mu \mathrm{m}$ pore size of the membrane

- Irregular nuclear outline

- Presence of tridimensional cellular sheets

$\circ$ High nuclear/cytoplasmic ratio 


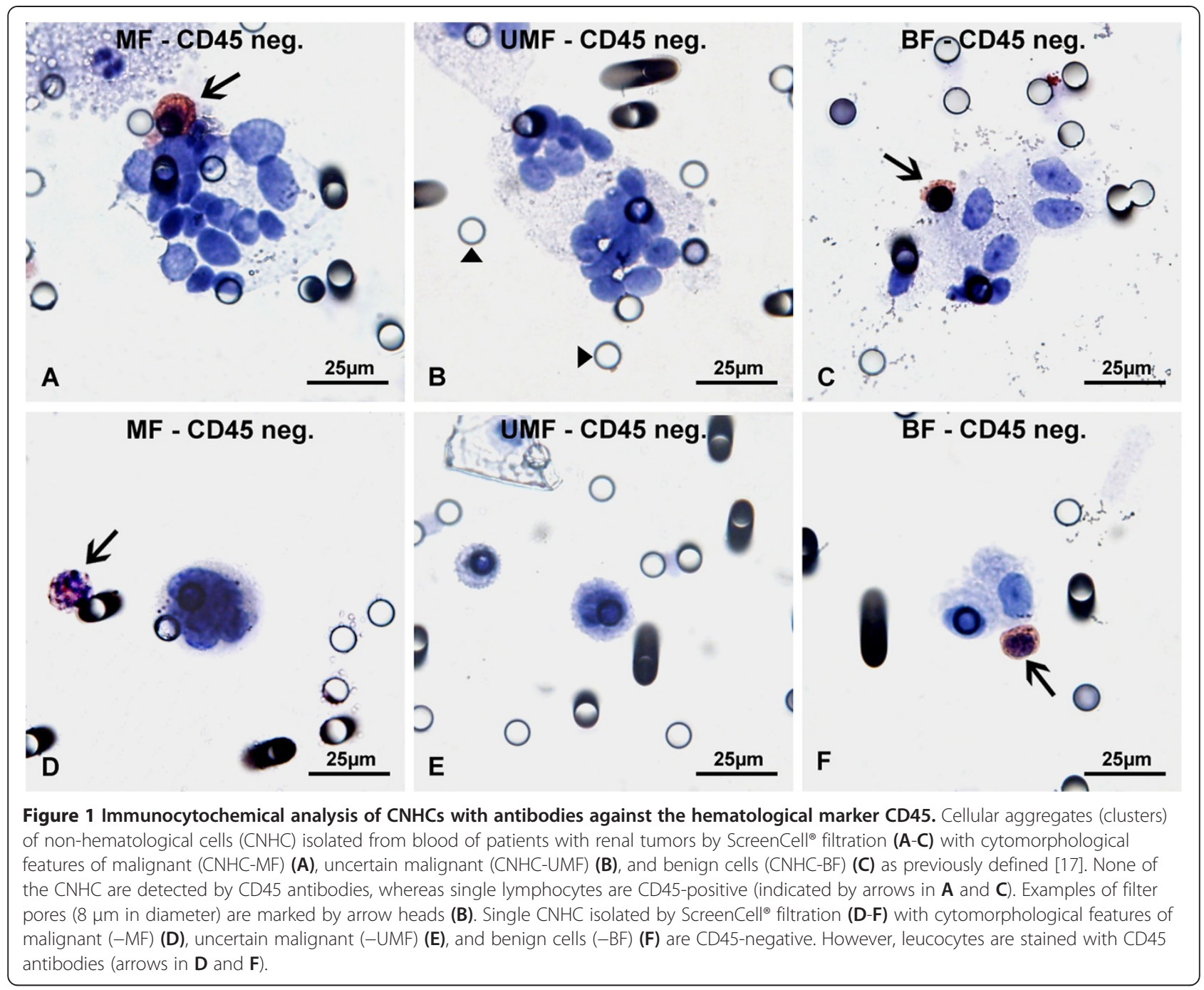

CNHC clusters were defined as CNHC-UMF when less than 4 of these criteria were seen (Figure 1B), whereas CNHC-BF did not show any of these characteristics (Figure 1C).

Single CNHC (Figure 1D-F) were classified as CNHCMF (Figure 1D) if all 3 of the following cytological criteria were present:

Nuclei larger than 3 times the calibrated $8 \mu \mathrm{m}$ pore
size
O Irregular nuclear outline
○ High nuclear/cytoplasmic ratio

If less than 3 of these criteria were present, the single cell was CNHC-UMF (Figure 1E). CNHC-BF cells showed none of the cellular features described above (Figure 1F). The number of cells was assessed by counting nuclei of single $\mathrm{CNHCs}$ and within $\mathrm{CNHC}$ clusters. The total numbers of $\mathrm{CNHCs}$ are listed in Table 2.
Immunocytochemical characterization of filtered cells After filtration the filters were dissembled from the device, air-dried over night at room temperature (RT) and then fixed in $4 \% \mathrm{~m} / \mathrm{V}$ formaldehyde (Labonord, Templemars, France) for $10 \mathrm{~min}$. After rehydration in Tris-buffered saline (TBS) for $10 \mathrm{~min}$, the filters were incubated in TBS-Triton (TBS containing $0.2 \%$ Triton X-100) (Merck, Darmstadt, Germany) for 5 min. Following a washing step with TBS, hydrogen peroxidase blocking solution (Dako, Glostrup, Denmark) was applied for 10 min followed by incubation with Ultra V Block (Dako, Glostrup, Denmark) at RT for $5 \mathrm{~min}$. To circumvent the effect of a possible EMT-associated low expression of epithelial antigens like cytokeratins in CTCs/CTMs and because renal cell cancers only weakly express epithelial cell adhesion molecule (EpCAM) [26], carbonic anhydrase IX (CAIX) was used as a marker. This protein is overexpressed in $100 \%$ of clear cell renal cell carcinomas and $57 \%$ of papillary renal cell carcinomas [27] but is not expressed in normal renal tissue [28]. 
Table 2 Summary of the results of cytomorphological classification of CNHCs detected by ScreenCell ${ }^{\circledR}$ filtration in 8 ml of venous blood of patients with benign $(n=10)$, malignant $(n=30)$ renal tumors and healthy controls $(n=20)$

\begin{tabular}{|c|c|c|c|c|c|c|c|c|c|c|c|c|c|c|c|c|}
\hline \multirow[b]{3}{*}{$\begin{array}{l}\text { Patient } \\
\text { number }\end{array}$} & \multirow[b]{3}{*}{$\begin{array}{l}\text { Histological } \\
\text { diagnosis }\end{array}$} & \multirow{2}{*}{\multicolumn{3}{|c|}{ Clinical data }} & \multicolumn{12}{|c|}{ Number of CNHC / $8 \mathrm{ml}$} \\
\hline & & & & & \multicolumn{3}{|c|}{ Time point $A^{*}$} & \multicolumn{3}{|c|}{ Time point $\mathrm{B}^{* *}$} & \multicolumn{3}{|c|}{ Time point $C^{* * *}$} & \multicolumn{3}{|c|}{ Time point $D^{* * * * *}$} \\
\hline & & TNM & Grade & $\begin{array}{c}\text { Venous } \\
\text { invasion }\end{array}$ & $\overline{M F}$ & UMF & $\overline{B F}$ & MF & UMF & $\overline{B F}$ & MF & UMF & $\mathrm{BF}$ & MF & UMF & $\mathrm{BF}$ \\
\hline 26 & angiomyolipoma & - & - & no & 0 & 2 & 0 & 0 & 0 & 0 & 0 & 0 & 0 & 0 & 0 & 0 \\
\hline 33 & angiomyolipoma & - & - & no & 0 & 0 & 0 & 0 & 0 & 0 & 0 & 0 & 0 & 0 & 0 & 0 \\
\hline 29 & benign cyst & - & - & - & 0 & 0 & 0 & 0 & 10 & 0 & 0 & 0 & 30 & 2 & 0 & 0 \\
\hline 18 & cyst. nephroma & - & - & - & 51 & 4 & 0 & 2 & 0 & 0 & 0 & 127 & 30 & 30 & 380 & 0 \\
\hline 3 & oncocytoma & - & - & no & 0 & 560 & 2 & 0 & 0 & 0 & 0 & 0 & 0 & 0 & 251 & 195 \\
\hline 4 & oncocytoma & - & - & no & 0 & 0 & 0 & 0 & 2 & 0 & 0 & 40 & 8 & 0 & 2 & 3 \\
\hline 6 & oncocytoma & - & - & no & 0 & 3 & 0 & 0 & 0 & 0 & 2 & 35 & 35 & 0 & 19 & 11 \\
\hline 14 & oncocytoma & - & - & no & 0 & 0 & 0 & 0 & 39 & 0 & 37 & 8 & 0 & 21 & 5 & 0 \\
\hline 17 & oncocytoma & - & - & no & 2 & 136 & 0 & 0 & 0 & 0 & 1 & 0 & 0 & 2 & 0 & 35 \\
\hline 38 & oncocytoma & - & - & no & 0 & 0 & 4 & 0 & 0 & 0 & 0 & 0 & 0 & 0 & 0 & 0 \\
\hline 1 & $\mathrm{cCRCC}$ & T2aNOMO & 2 & yes & 0 & 0 & 0 & 0 & 0 & 0 & ND & ND & ND & ND & ND & ND \\
\hline 2 & cCRCC & T3aNOMO & 2 & yes & 0 & 0 & 0 & 0 & 0 & 3 & 0 & 10 & 0 & 0 & 0 & 0 \\
\hline 7 & $\mathrm{cCRCC}$ & T2aNOMO & 2 & no & 0 & 0 & 0 & 0 & 0 & 0 & 0 & 6 & 0 & ND & ND & ND \\
\hline 9 & $\mathrm{cCRCC}$ & T1bNOMO & 2 & no & 3 & 19 & 5 & 0 & 0 & 0 & ND & ND & ND & 0 & 0 & 0 \\
\hline 10 & ccRCC & T1NOMO & 2 & no & 16 & 0 & 10 & 0 & 0 & 0 & 0 & 0 & 3 & 0 & 22 & 16 \\
\hline 11 & $\mathrm{cCRCC}$ & T1N0M0 & 2 & no & 0 & 0 & 0 & 2 & 0 & 0 & $\mathrm{ND}$ & ND & ND & 0 & 0 & 0 \\
\hline 13 & $\mathrm{cCRCC}$ & T3aNOMO & 3 & yes & 0 & 19 & 0 & 0 & 0 & 0 & 22 & 158 & 30 & ND & ND & ND \\
\hline 15 & $\mathrm{cCRCC}$ & T1aNOMO & 2 & no & 0 & 0 & 0 & 0 & 0 & 0 & 0 & 0 & 0 & 0 & 0 & 0 \\
\hline 16 & $\mathrm{cCRCC}$ & T1aNOMO & 2 & no & 62 & 56 & 0 & 0 & 0 & 0 & 0 & 0 & 0 & 0 & 0 & 0 \\
\hline 19 & $\mathrm{cCRCC}$ & T1aNoM0 & 1 & no & 1 & 0 & 0 & 0 & 0 & 0 & 0 & 0 & 0 & 0 & 3 & 5 \\
\hline 20 & $\mathrm{cCRCC}$ & T3aNOMO & 3 & yes & 13 & 5 & 0 & 0 & 0 & 0 & 20 & 319 & 58 & ND & ND & ND \\
\hline 22 & cCRCC & T1aNoMo & 1 & no & 0 & 32 & 0 & 1 & 0 & 0 & 11 & 0 & 0 & ND & ND & ND \\
\hline 23 & $\mathrm{cCRCC}$ & T1aNOMO & 1 & no & 1 & 0 & 0 & 0 & 1 & 0 & 2 & 0 & 10 & 5 & 12 & 15 \\
\hline 24 & cCRCC & T1NOMO & 1 & no & ND & ND & ND & 0 & 0 & 5 & 0 & 1 & 0 & 0 & 0 & 0 \\
\hline 25 & cCRCC & T1aNOMO & 2 & no & 0 & 1 & 0 & 0 & 0 & 0 & 0 & 1 & 20 & ND & ND & ND \\
\hline 28 & $\mathrm{cCRCC}$ & T1bNOMO & 1 & no & 0 & 0 & 0 & 0 & 645 & 0 & 5 & 5 & 25 & 0 & 36 & 12 \\
\hline 30 & $\mathrm{cCRCC}$ & T1NOMO & 3 & no & 0 & 0 & 0 & 31 & 227 & 4 & 0 & 0 & 0 & 0 & 67 & 64 \\
\hline 32 & $\mathrm{cCRCC}$ & T1aNOMO & 2 & no & 1 & 0 & 0 & 1 & 0 & 0 & 3 & 26 & 15 & ND & ND & ND \\
\hline 34 & cCRCC & T1aNoMo & 2 & no & 0 & 0 & 0 & 0 & 26 & 51 & 0 & 18 & 0 & ND & ND & ND \\
\hline 35 & $\mathrm{cCRCC}$ & T1aNOMO & 2 & no & 0 & 0 & 0 & 0 & 0 & 0 & ND & ND & ND & 0 & 20 & 0 \\
\hline 36 & $\mathrm{cCRCC}$ & T1aNOMO & 3 & no & 2 & 125 & 3 & 0 & 0 & 0 & 2 & 1 & 7 & 0 & 0 & 0 \\
\hline 40 & $\mathrm{cCRCC}$ & T1aNOMO & 3 & no & 0 & 23 & 0 & 0 & 0 & 0 & 0 & 0 & 15 & 0 & 0 & 0 \\
\hline 41 & $\mathrm{cCRCC}$ & T1aNOMO & 3 & no & 0 & 0 & 0 & 0 & 0 & 0 & 1 & 0 & 0 & 3 & 74 & 4 \\
\hline 42 & $\mathrm{CCRCC}$ & T1NOMO & 1 & no & 0 & 0 & 0 & 0 & 0 & 0 & 0 & 22 & 44 & 58 & 124 & 98 \\
\hline 27 & pap.RCC & T1bNOMO & 3 & no & 0 & 0 & 0 & 0 & 0 & 0 & 0 & 0 & 0 & 1 & 6 & 0 \\
\hline 8 & pap.RCC & T1N0M0 & 2 & no & ND & ND & ND & 0 & 0 & 0 & 0 & 0 & 0 & 0 & 0 & 0 \\
\hline 12 & pap.RCC & T3aNOMO & 3 & yes & 0 & 0 & 5 & 0 & 0 & 0 & 11 & 0 & 0 & ND & ND & ND \\
\hline 31 & pap.RCC & T1aNoMo & 2 & no & 0 & 0 & 0 & 0 & 0 & 0 & ND & ND & ND & ND & ND & ND \\
\hline 37 & pap.RCC & T2aNOMO & 2 & no & 0 & 0 & 100 & 19 & 79 & 18 & 1 & 0 & 4 & ND & ND & ND \\
\hline 39 & reg RCC & T2aNOMO & 2 & yes & 0 & 0 & 1 & 1 & 0 & 0 & 1 & 0 & 0 & 1 & 0 & 0 \\
\hline $\mathrm{C} 1$ & Control & - & - & - & 0 & 0 & 1 & - & - & - & - & - & - & - & - & - \\
\hline
\end{tabular}


Table 2 Summary of the results of cytomorphological classification of CNHCs detected by ScreenCell ${ }^{\otimes}$ filtration in $8 \mathrm{ml}$ of venous blood of patients with benign $(n=10)$, malignant $(n=30)$ renal tumors and healthy controls $(n=20)$ (Continued)

\begin{tabular}{|c|c|c|c|c|c|c|c|c|c|c|c|c|c|c|c|c|}
\hline C2 & Control & - & - & - & 0 & 0 & 0 & - & - & - & - & - & - & - & & - \\
\hline C3 & Control & - & - & - & 0 & 2 & 2 & - & - & - & - & - & - & - & . & - \\
\hline C4 & Control & - & - & - & 0 & 83 & 100 & - & - & - & - & - & - & - & & - \\
\hline C5 & Control & - & - & - & 0 & 0 & 0 & - & - & - & - & - & - & - & & - \\
\hline C6 & Control & - & - & - & 0 & 0 & 0 & - & - & - & - & - & - & - & & - \\
\hline C7 & Control & - & - & - & 0 & 0 & 12 & - & - & - & - & - & - & - & & - \\
\hline C8 & Control & - & - & - & 0 & 0 & 0 & - & - & - & - & - & - & - & & - \\
\hline C9 & Control & - & - & - & 0 & 1 & 0 & - & - & - & - & - & - & - & & - \\
\hline C10 & Control & - & - & - & 0 & 0 & 0 & - & - & - & - & - & - & - & & - \\
\hline C11 & Control & - & - & - & 0 & 1 & 1 & - & - & - & - & - & - & - & & - \\
\hline $\mathrm{C} 12$ & Control & - & - & - & 0 & 0 & 0 & - & - & - & - & - & - & - & & - \\
\hline C13 & Control & - & - & - & 0 & 1 & 2 & - & - & - & - & - & - & - & & - \\
\hline C14 & Control & - & - & - & 0 & 0 & 0 & - & - & - & - & - & - & - & & - \\
\hline C15 & Control & - & - & - & 0 & 0 & 0 & - & - & - & - & - & - & - & & - \\
\hline C16 & Control & - & - & - & 0 & 27 & 5 & - & - & $\begin{array}{lll}- & \\
-1\end{array}$ & - & - & - & $\begin{array}{lll}- & \\
-1\end{array}$ & & - \\
\hline C17 & Control & - & - & - & 0 & 1 & 7 & - & - & - & - & - & - & - & & - \\
\hline C18 & Control & - & - & - & 0 & 0 & 0 & - & - & - & - & - & - & - & & - \\
\hline C19 & Control & - & - & - & 0 & 0 & 0 & - & - & - & - & - & - & - & & - \\
\hline C20 & Control & - & - & - & 0 & 1 & 0 & - & - & - & - & - & - & - & & - \\
\hline
\end{tabular}

* One day before surgery.

** During surgery, after the removal of the tumor.

*** One day after surgery.

**** Eight days after surgery.

ND Not done (sample not available).

The filters were incubated with primary antibodies directed against CAIX (rabbit IgG, NB100-417, Novus Biologicals, Littleton, USA; $3.5 \mu \mathrm{g} / \mathrm{ml}$ ), CD31 (mouse IgG1, M0823, Dako, Glostrup, Denmark; $1 \mu \mathrm{g} / \mathrm{ml}$ ) or CD45 (mouse IgG1, M0855, Dako, Glostrup, Denmark; $2.4 \mu \mathrm{g} / \mathrm{ml}$ ) diluted in Antibody Diluent (Dako, Glostrup, Denmark) for $30 \mathrm{~min}$ at RT followed by application of primary antibody enhancer (Dako, Glostrup, Denmark) for $15 \mathrm{~min}$. Thereafter the filters were incubated with labelled polymer-HRP Anti-Mouse + Anti-Rabbit (Dako, Glostrup, Denmark) for $10 \mathrm{~min}$. AEC substrate chromogen (Dako, Glostrup, Denmark) was applied for $10 \mathrm{~min}$ and rinsed off with distilled water prior to counterstaining with hematoxylin (Merck, Darmstadt, Germany) as described above. Respective non-immune rabbit IgG and isotype-matched monoclonal antibodies were used as controls. Cultured 769-P and HIAEC cells were spiked in blood, filtered and stained like patient samples and served as positive or negative control for staining, enumeration and array-CGH experiments.

\section{Laser capture microdissection and whole genome} amplification of selected filtered cells

Isolation of selected CNHCs was carried out by laser capture microdissection (P.A.L.M., Zeiss, Munich, Germany).
Before laser capture microdissection, all non-target cells and cellular debris were removed by laser ablation. The polycarbonate filter was then cut with a pulsed laser beam and the membrane and target cells were catapulted into the lid of a $200 \mu \mathrm{l}$ PCR tube, which contained $10 \mu \mathrm{l}$ of WGA-4 fragmentation and lysis buffer (\#WGA4, Sigma-Aldrich, St. Louis, USA) (Figure 2). An exemplary laser capturing is shown in Additional file 1: Movie 1. For control purposes neutrophilic granulocytes, which were subjected to the same filtration and staining procedures like patient samples, were as well isolated by laser capture microdissection and forwarded to whole genome amplification (WGA). WGA was performed as previously described [29] with minor modifications using the GenomePlex Single Cell Whole Genome Amplification Kit (Sigma-Aldrich, St. Louis, USA). Briefly, the captured cells were digested in $10 \mu \mathrm{l}$ fragmentation and lysis buffer, followed by GenomePlex library preparation. Amplification was performed by adding $7.5 \mu \mathrm{l}$ of $10 \times$ amplification master mix, $48.5 \mu \mathrm{l}$ nuclease free water and $5 \mu \mathrm{l}$ WGA DNA polymerase. After whole genome amplification, DNA was purified using the GenElute PCR Clean-Up Kit (SigmaAldrich, St. Louis, USA). DNA concentration and purity 


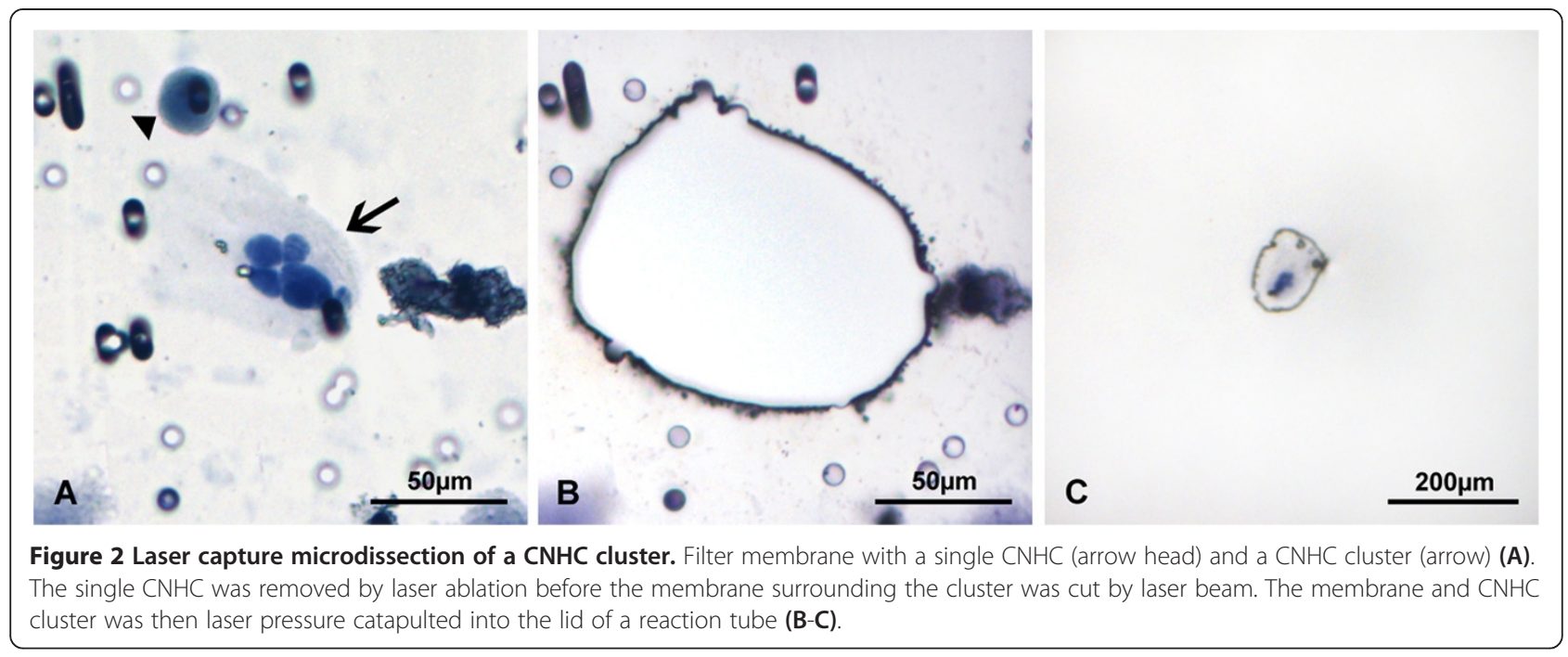

was determined by Nanodrop spectrophotometer (Thermo Fisher Scientific, Waltham, USA). DNA quality was assessed by multiplex PCR as previously described [25]. Samples showing three to four DNA bands between 100 and $400 \mathrm{bp}$ were regarded as of high DNA quality.

\section{Array-CGH}

Array-CGH was performed using SurePrint G3 Human CGH Microarrays $8 \times 60 \mathrm{~K}$ (Agilent Technologies, Santa Clara, USA). Prior to labelling, genomic DNA derived from snap frozen and FFPE tissues as well as the corresponding reference DNA were digested by Alu I and Rsa I (Promega, Fitchburg, USA) according to the supplier's instructions. Amplified DNA of CNHCs and the corresponding amplified reference DNA (Promega, Fitchburg, USA) showed mean DNA size distributions of 400 $600 \mathrm{bp}$ and therefore provided suitable templates for array-CGH without any digestion step. The purified samples were labelled with the Bioprime Array CGH Genomic Labeling System (Life Technologies, Carlsbad, USA). Briefly, $250 \mathrm{ng}$ of sample DNA and $250 \mathrm{ng}$ of female or male reference DNA (Promega, Fitchburg, USA) were labelled with dCTP-Cy5 and dCTP-Cy3 (GE Healthcare, Little Chalfont, UK), respectively. Subsequently, DNA was purified with Amicon Ultracel-30 filters (Millipore, Billerica, USA) and mixed in equal amounts. The mixture was hybridized to a $60 \mathrm{~K}$ array $\mathrm{ON}$ using the Oligo aCGH/ChIP-on-chip Hybridization kit (Agilent Technologies, Santa Clara, USA). Following hybridization, the array was washed and scanned (Agilent Technologies, Santa Clara, USA) as recommended by the manufacturer. Data analysis was performed with Agilent Genomic Workbench Lite Edition 6.5.0.18. (Agilent Technologies, Santa Clara, USA). The following settings were used for tumor tissues: ADM-2, threshold 8.0, with at least 10 consecutive oligos with an absolute $\log$ ratio of 0.22 . For amplified DNA the algorithm ADM-2, threshold 9.3 was used with at least 100 consecutive oligos with an absolute log ratio of 0.30 .

\section{Definition of thresholds and controls for array-CGH}

As it was our purpose to characterize CNHC clusters, pools of leucocytes and 769-P cells were used to test the detection limits of genetic aberrations of the array-CGH method. 769-P cells and leucocytes were subjected to ScreenCell ${ }^{\odot}$ filtration, microdissected from the filters, the DNA was subjected to WGA and further analysed by array-CGH. There was concordance of gains and losses of chromosomal DNA detected in amplified pools of ten 769-P cells and non-amplified DNA from cultured 769-P cells [30] (Figure 3). From this comparison we estimated that deletions of approximately $\sim 6.8 \mathrm{Mb}$ can be detected in pools of ten 769-P cells (chromosome 9, genomic position 16.2-23.0 Mb) which is sufficient to indicate larger scale aberrations in RCC [31]. The DNA of isolated pools of 10 leucocytes from blood of a healthy individual, representing a balanced genome, was used to set the thresholds for the detection limits of gains and losses by array-CGH in our study. In contrast to cell cultured cells, the array-CGH profiles of amplified DNA of CNHCs demonstrated slightly noisier ratio profiles, as we expected if going from an artificial cell culture system to clinical samples. By applying the above mentioned threshold settings, gains and losses could be reliably detected (Figure 3).

\section{Statistical analysis}

We investigated if the presence or absence of CNHC types (categorized as binary variables) differed between time points $\mathrm{A}-\mathrm{D}$, using Chi-square tests. Furthermore, median, minimum and maximum were used to describe the number of CNHCs of each type and for every time 


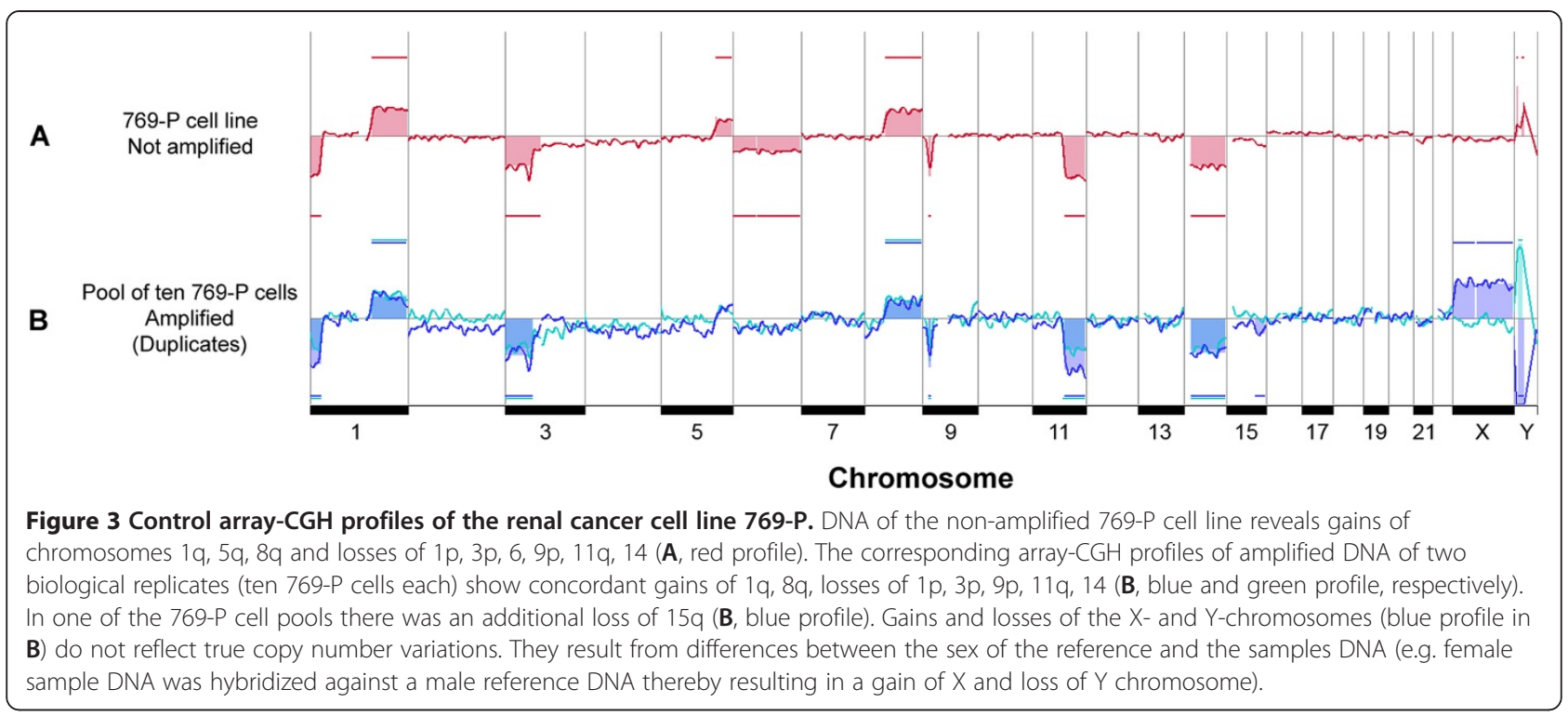

point. The associations between numbers of CNHCs of each type with tumor size, venous invasion and differentiation grade were explored using nonparametric methods. A p-value of $<0.05$ was considered to indicate statistical significance. All p-values were regarded in an explorative sense. The statistical calculations were performed using the SPSS software package, version 20.0 (IBM, Armonk, USA).

\section{Results}

\section{Spiking experiments}

The average number of recovered 769-P cells for 50,10 and 2 spiked cells were 45.3 (SD 2.1), 8.7 (SD 1.5), and 1.7 (SD 0.6), respectively. The average recovery rates of 769-P were 91\%, 87\% and 83\% for 50, 10 and 2 spiked 769-P cells, respectively which compares to sensitivity rates published by Desitter et al. for the ScreenCell ${ }^{\circ}$ filtration device [15].

\section{Cytomorphological analysis of CNHC types in patients with renal tumors and healthy controls}

Overall CNHCs of the MF-type were detected more frequently in renal cancer patients $(29 \%)$ as compared to healthy controls $(0 \%)(\mathrm{p}=0.014)$. CNHC-MF were also found in $20 \%$ of cases with benign renal tumors which was not significantly different from the frequency found in healthy controls $(p=0.103)$. However in healthy controls CNHC-MF were not found. CNHC-UMF and -BF types were identified in the blood of $29 \%$ and $21 \%$ of the renal cancer patients, in $50 \%$ and $20 \%$ of benign renal tumor patients as well as in $40 \%$ and $40 \%$ of healthy individuals (Figure 4).

A summary of the results of the cytomorphological analyses and the number of cells of all patients and time points is provided in Table 2.
Overall, one day before surgery (time point A) $26 \%$, $34 \%$, and $21 \%$ of the blood samples were positive for CNHC-MF, -UMF and -BF, respectively. However, during surgery, after removal of the renal tumor (time point B) CNHC-MF, -UMF and -BF were found in only $18 \%$, $20 \%$ and $13 \%$ of samples, respectively. One day after surgery (time point $\mathrm{C}$ ) there was a significant increase in the number of blood samples positive for CNHC-MF $(40 \%, \mathrm{p}=0.040),-\mathrm{UMF}(43 \%, \mathrm{p}=0.045)$ and BF $(43 \%$, 0.004). Eight days after surgery (time point D) $48 \%$ of the samples were positive for CNHC-UMF and 38\% were positive for CNHC-BF, whereas in only $31 \%$ of samples CNHC-MF were found (Figure 5).

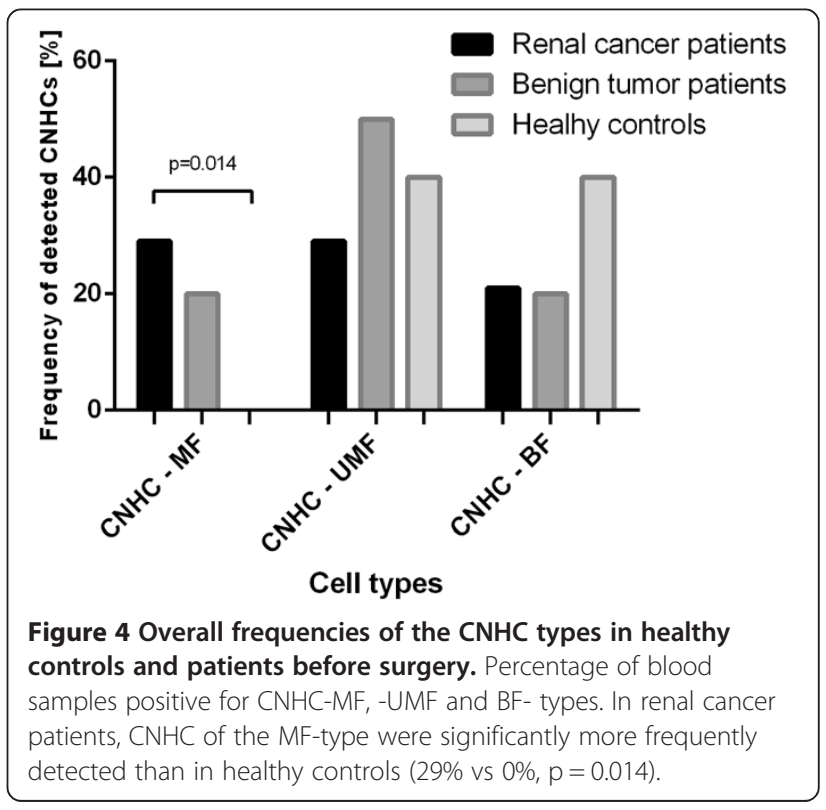




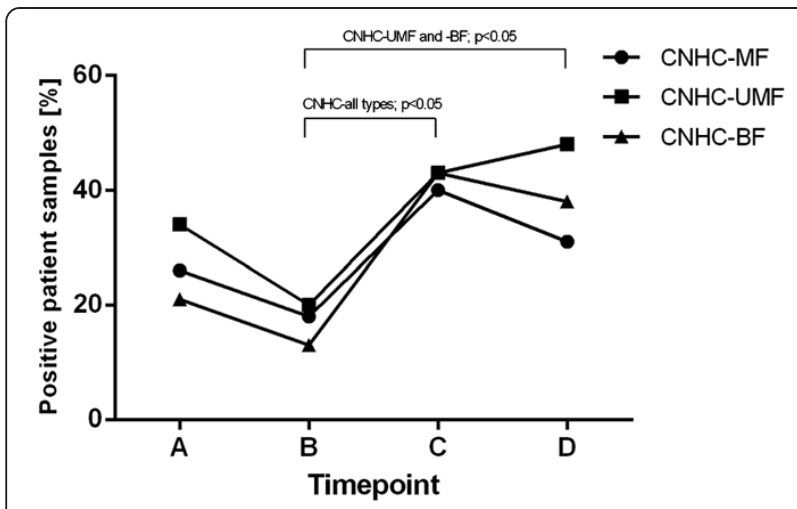

Figure 5 Percentage of patient samples positive for CNHC-MF, -UMF and $\mathrm{BF}$ at different time points of sampling. Percentage of blood samples positive for CNHC-MF (circle), CNHC-UMF (rectangle), and CNHC-BF (triangle) one day before surgery (time point $\mathbf{A}$ ), during surgery, after the removal of the tumor (time point $\mathbf{B}$ ), one day after surgery (time point $\mathbf{C}$ ), and 8 days after surgery (time point $\mathbf{D}$ ). There was no significant change in the percentage of blood samples positive for $\mathrm{CNHC}$ of any type after surgery (time points $\mathbf{C}$ and $\mathbf{D}$, respectively) as compared to before surgery (time point A). However, a significant increase of samples positive for $\mathrm{CNHCs}$ of every type was found at time point $\mathbf{C}$ as compared to time point $\mathbf{B}(\mathrm{p}<0.05$, each). Blood samples positive for CNHC-UMF and CNHCBF but not CNHC-MF, were also more frequently detected at time point $\mathbf{D}$ as compared to time point $\mathbf{B}$.

The cytomorphological CNHC types, CNHC-MF,-UMF,-BF either as single cells or clusters were found at every time point in patients regardless of the histological tumor diagnosis (Table 2).

The median number of CNHC-MF per $8 \mathrm{ml}$ of blood was 3 cells (range: 1-62) before surgery (time point A), 2 cells (range: $1-31$ ) during the surgery (time point $B$ ), 3 cells (range: $1-37$ ) one day after surgery (time point $C$ ) as well as 3 cells (range: 1-58) eight days after surgery (time point D) (Figure 6A). The median number of CNHC-UMF per $8 \mathrm{ml}$ of blood was 19 cells (range: $1-560$ ) at time point $\mathrm{A}, 33$ cells $/ 8 \mathrm{ml}$ (range: $1-645$ ) at time point $\mathrm{B}, 18$ cells $/ 8 \mathrm{ml}$ (range: $1-319$ ) at time point $\mathrm{C}$ and 21 cells $/ 8 \mathrm{ml}$ (range $2-380$ ) at time point D (Figure 6B).
Cells with benign features represented with a median number of 4 cells $/ 8 \mathrm{ml}$ (range: $1-100$ ) at time point A, 5 cells/ $8 \mathrm{ml}$ (range: $3-51$ ) at time point $\mathrm{B}, 20$ cells $/ 8 \mathrm{ml}$ (range: 3-58) at time point $C$ and 15 cells/8 $\mathrm{ml}$ (range: $3-195$ ) at time point $\mathrm{D}$ (Figure $6 \mathrm{C}$ ). In renal cancer patients there was no correlation between histopathological tumor parameters (tumor size, grade of differentiation) and detection of $\mathrm{CNHC}$ regardless of type or time point examined (Additional file 2: Table S1 and Additional file 3: Table $\mathrm{S} 2$ ). However, one day after surgery (time point $\mathrm{C}$ ) higher numbers of CNHC-MF were detected in patients with RCC with venous invasion as compared to those cases without venous invasion $(\mathrm{p}=0.013)$. This was not found at any of the other time points investigated (Additional file 4: Table S3).

In the blood of healthy controls no CNHC-MF were detected. In three out of 20 cases (15\%) we found CNHC clusters, primarily of the BF- (14 clusters) and UMFtypes (6 clusters). In 7 out of 20 cases (35\%) we found single CNHCs, mostly of the BF- (13 cells) and less frequently the UMF-types (5 cells). Overall, 0\%, 40\%, and $40 \%$ of the blood samples from healthy controls were positive for $\mathrm{CNHC}-\mathrm{MF},-\mathrm{UMF}$ and $-\mathrm{BF}$, respectively (Table 2). All detected CNHCs were negative for CAIX or CD45. However, $4 \mathrm{CNHC}$ clusters of the -BF type and 2 of the -UMF type were positive for CD31.

\section{Immunocytochemical analysis of CNHC in patients with renal tumors}

Results of the immunocytochemical analyses are compiled in Table 3 .

On the 53 filters stained with antibodies against CD45 (Figure 1A-F), hematological cells including lymphocytes and polymorphic nuclear granulocytes showed a positive staining, whereas the CNHC-MF, -UMF and -BF, either present as cell clusters (Figure $1 \mathrm{~A}-\mathrm{C}$ ) or as single cells (Figure 1D-F) were without exception negative.

On the 46 filters stained with antibodies against the RCC marker CAIX (Figure 7), $28 \mathrm{CNHC}$ clusters were
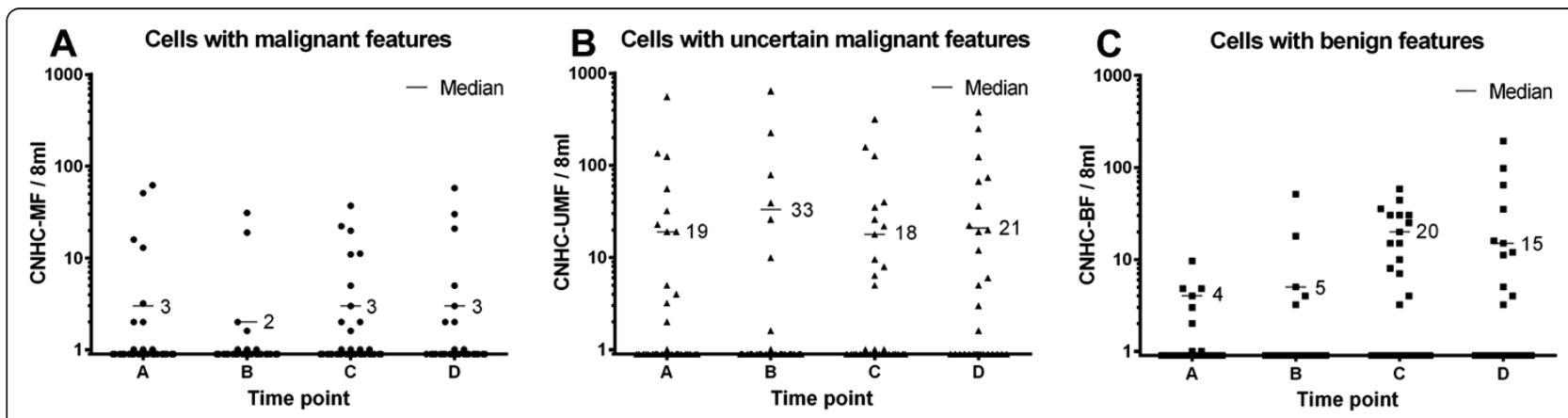

Figure 6 Numbers of CNHC-types at different time points. Numbers of CNHC-MF (A), -UMF (B), and -BF (C) per 8 ml of venous blood at time points A-D. Median cell numbers are given for each time point. 
Table 3 Summary of the immunocytochemical analysis of CNHCs with antibodies against CD45, CD31, and CAIX

\begin{tabular}{|c|c|c|c|c|c|c|}
\hline & \multicolumn{3}{|c|}{ Single $\mathrm{CNHCs}$ positive with CD45/CAIX/CD31 antibodies } & \multicolumn{3}{|c|}{ CNHC clusters positive with CD45/CAIX/CD31 antibodies } \\
\hline & \multicolumn{3}{|c|}{$\mathrm{N}(\%)$} & \multicolumn{3}{|c|}{$\mathrm{N}(\%)$} \\
\hline & CD45 & CAIX & CD31 & CD45 & CAIX & CD31 \\
\hline CNHC-MF & $0 / 3(0 \%)$ & $5 / 9(56 \%)$ & $0 / 1(0 \%)$ & $0 / 5(0 \%)$ & None detected & $3 / 3(100 \%)$ \\
\hline CNHC-UMF & $0 / 4(0 \%)$ & $0 / 4(0 \%)$ & $1 / 3(33 \%)$ & $0 / 12(0 \%)$ & $1 / 16(6 \%)$ & $17 / 17(100 \%)$ \\
\hline CNHC-BF & $0 / 2(0 \%)$ & $0 / 1(0 \%)$ & $0 / 6(0 \%)$ & $0 / 8(0 \%)$ & $0 / 12(0 \%)$ & $8 / 13(62 \%)$ \\
\hline
\end{tabular}

detected. None exhibited cytological features of malignancy, 16 were classified as CNHC-UMF and 12 were CNHC-BF. Of the 16 CNHC-UMF clusters, one (6\%) was decorated by CAIX antibodies (Figure 7A), 15 (94\%) were negative (Figure $7 \mathrm{~B}$ ), as was the case with the 12 CNHC-BF (Figure 7C). Nine single CNHC-MF were detected, 5 (56\%) of which exhibited positive cytoplasmic reactivity (Figure 7D), whereas 4 (44\%) were negative (Figure 7E). Only 4 single $\mathrm{CNHC}$-UMF and one $\mathrm{CNHC}-\mathrm{BF}$ were found and these cells were also CAIXnegative (Figure 7F and 7G, respectively).

Immunocytochemical analysis of 14 filters with antibodies against the endothelial cell marker CD31 (Figure 8) yielded 3 CNHC-MF- and 17 CNHC-UMF cell clusters, all of which were $\mathrm{CD} 31$ positive (Figure $8 \mathrm{~A}$ and $\mathrm{B}$, respectively), as were $8(62 \%)$ of the $13 \mathrm{CNHC}$-BF clusters (Figure $8 \mathrm{C}$ ). Of single cells, only one cell with UMF was CD31 positive.

\section{Array-CGH}

After WGA, 55 out of 115 (48\%) stained microdissected cells yielded DNA products. According to the multiplex PCR, the DNA quality of $49 \%$ (27 of 55) of these cells was suitable for array-CGH. Six of CNHC-MF- and 6 of CNHC-UMF-types were selected for array-CGH analysis. All passed multiplex quality control and yielded informative array-CGH profiles. The DNA of the CNHC clusters and the respective renal tumor tissues, one case of papillary RCC (Figure 9), two cases of clear cell RCC (Figure 10 and Additional file 5: Figure S1), one oncocytoma (Figure 10) as well as one cystic nephroma (Additional file 5: Figure S1) were subjected to array-CGH analysis. The results are summarized in Table 4.

The chromosomal aberrations found in the DNA of the tumor tissues are in keeping with the genetic alterations reported for ccRCC, papRCC, and oncocytoma in the literature [31-33] and copy number aberration database

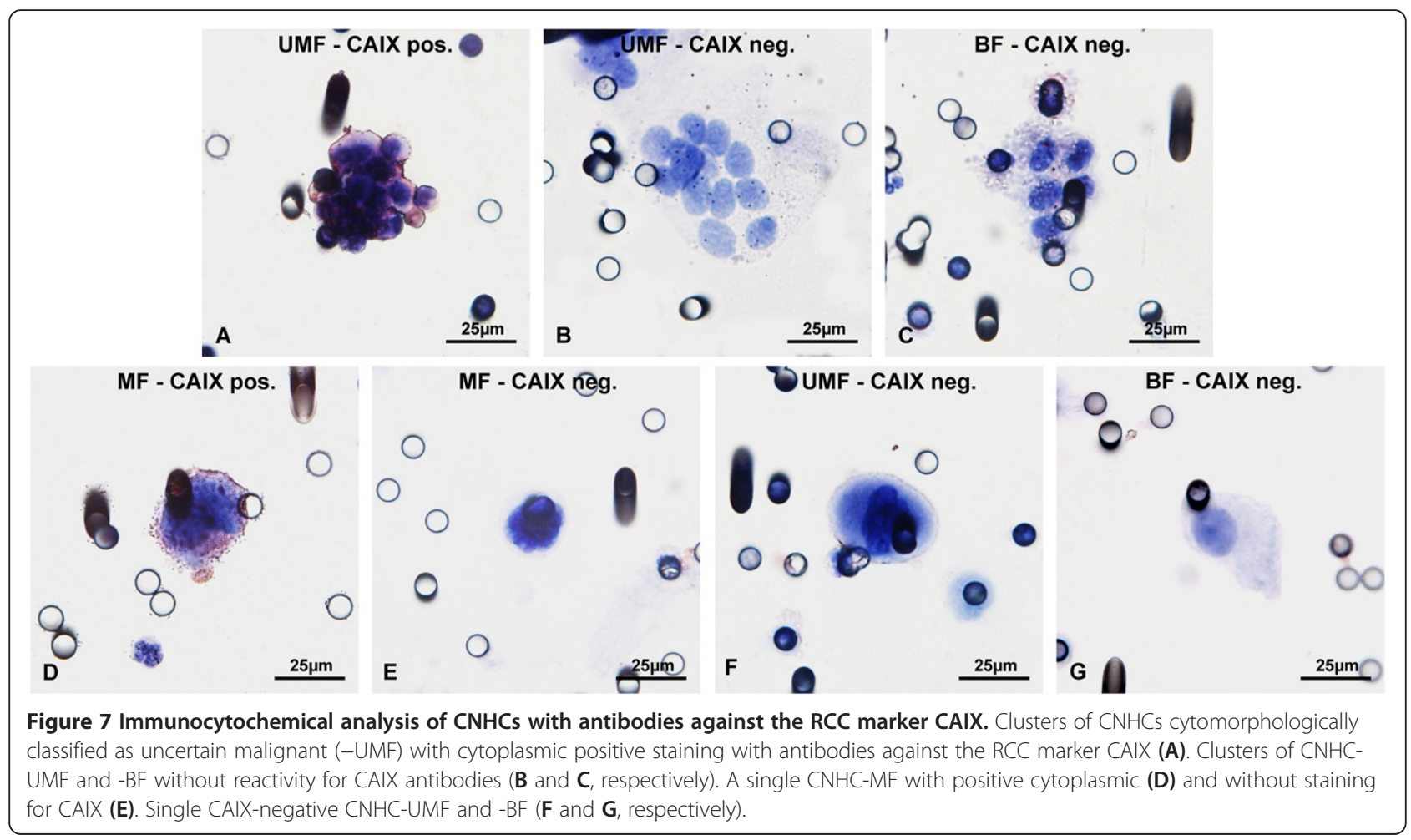




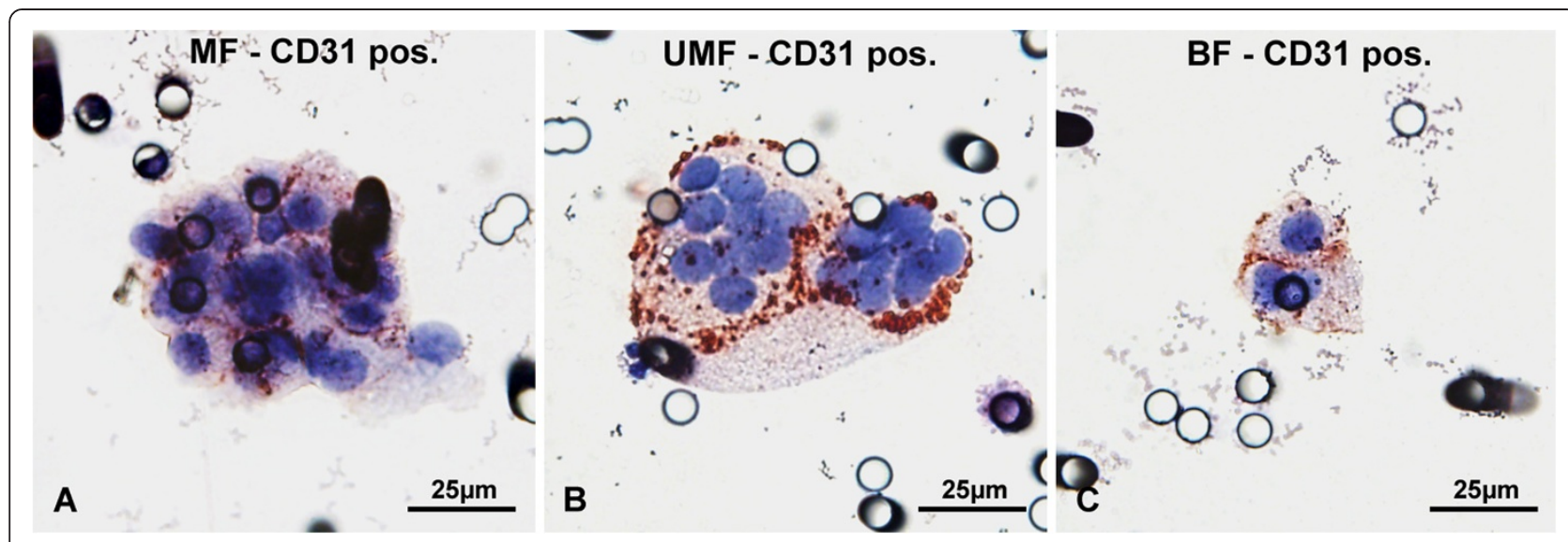

Figure 8 Immunocytochemical analysis of CNHCs with antibodies against the endothelial marker CD31. Clusters of CNHC-MF (A), -UMF (B), and -BF (C), with cytoplasmic staining for CD31.

(www.progenetix.net) [34]. DNA generated from a benign renal cyst of one patient (patient \# 18) was of insufficient quality for analysis by array-CGH. Irrespective of the cytomorphological type, most of the $\mathrm{CNHC}$ clusters showed a balanced genome. In only two of the $12(17 \%)$ CNHC clusters, one of which was a MF- and the other one was a UMF- cytomorphological type chromosomal aberrations could be identified which did not match the patterns of chromosomal changes found in the respective renal tumors (Table 4).

\section{Discussion}

We evaluated the feasibility and utility of the ScreenCell ${ }^{\odot}$ filtration system for the detection of CTCs and CTMs in the blood of patients with RCC. We investigated if morphological features can be used to discriminate between malignant and non-malignant cells by applying array-CGH.

We found the ScreenCell $^{\circledR}$ filtration an easy to perform procedure which allowed for the detection of large cells (i.e. diameter of $>8 \mu \mathrm{m}$ ) after filtration of $8 \mathrm{ml}$ of diluted blood in $60 \%$ of patients with benign and in 53\% with malignant renal tumors one day before surgical intervention. According to their cytomorphological features, these cells either occurring as single cells or cellular clusters consisting of at least 3 cells were classified as CNHC-MF, -UMF or -BF using diagnostic criteria recently published by a panel of expert cytopathologists [17]. Surprisingly, each type of CNHCs was found in blood of patients with benign renal tumors including renal cysts, cystic nephroma, angiomyolipomas, oncocytomas as well as malignant papillary or clear cell RCCs. The presence of $\mathrm{CNHCs}$ did not correlate with histopathological features of the respective tumors including tumor size, histological diagnosis and grade of tumor differentiation. However, in patients with renal cancer a correlation between the $\mathrm{CNHC}-\mathrm{MF}$ numbers and histological venous invasion was found at time point $C$ (one day after surgery). At time point A (one day before surgery) CNHC-MF were also more frequently detected in renal cancer patients as compared to healthy controls.

Immunocytochemical analysis revealed that single cells or cellular clusters found on the filters could be regarded as $\mathrm{CNHCs}$ because they were invariably negative for CD45, an established marker for hematological cells [35]. Indeed, the results of the CD31 immunocytochemical staining and genetic analysis seem to indicate that most of the cellular CNHC clusters identified in our study may represent aggregations of circulating endothelial cells (CECs) rather than CTMs. More than half (62\%) of the clusters of CNHCs-BF-type and all of the $\mathrm{CNHC}$ of the -MF and -UMF types found on the filters analysed with antibodies against CD31 were positive, whereas only $6 \%$ of the CNHC-UMF- and none of the CNHC-BF clusters were positive on the filters stained for the RCC marker CAIX [36,37]. Although with lower staining intensity as compared to endothelial cells, neutrophilic granulocytes, some lymphocytes, monocytes and platelets can also be stained by the CD31 antibodies [38]. Therefore we cannot exclude that the CNHC clusters may contain some of these cell types as well. However, this is not supported by their cytomorphological features and negative staining results with CD45-antibodies.

In contrast to what was observed for the CNHC clusters, $56 \%$ of the single CNHC-MF on the filters analysed with antibodies against the renal cancer marker CAIX $[36,37]$ were positive and might thus represent "true" CTCs. Only 1 out of 10 single CNHC (10\%) was positive for CD31. Unfortunately, only DNA of insufficient quality could be generated from single CNHCs of any type precluding array-CGH characterisation of these cells.

Analysis of limited amounts of DNA, as in the analysis of CTCs is faced with several technical problems. Procedures of fixation and staining can decrease DNA quality and interfere with the whole genome amplification (WGA) 


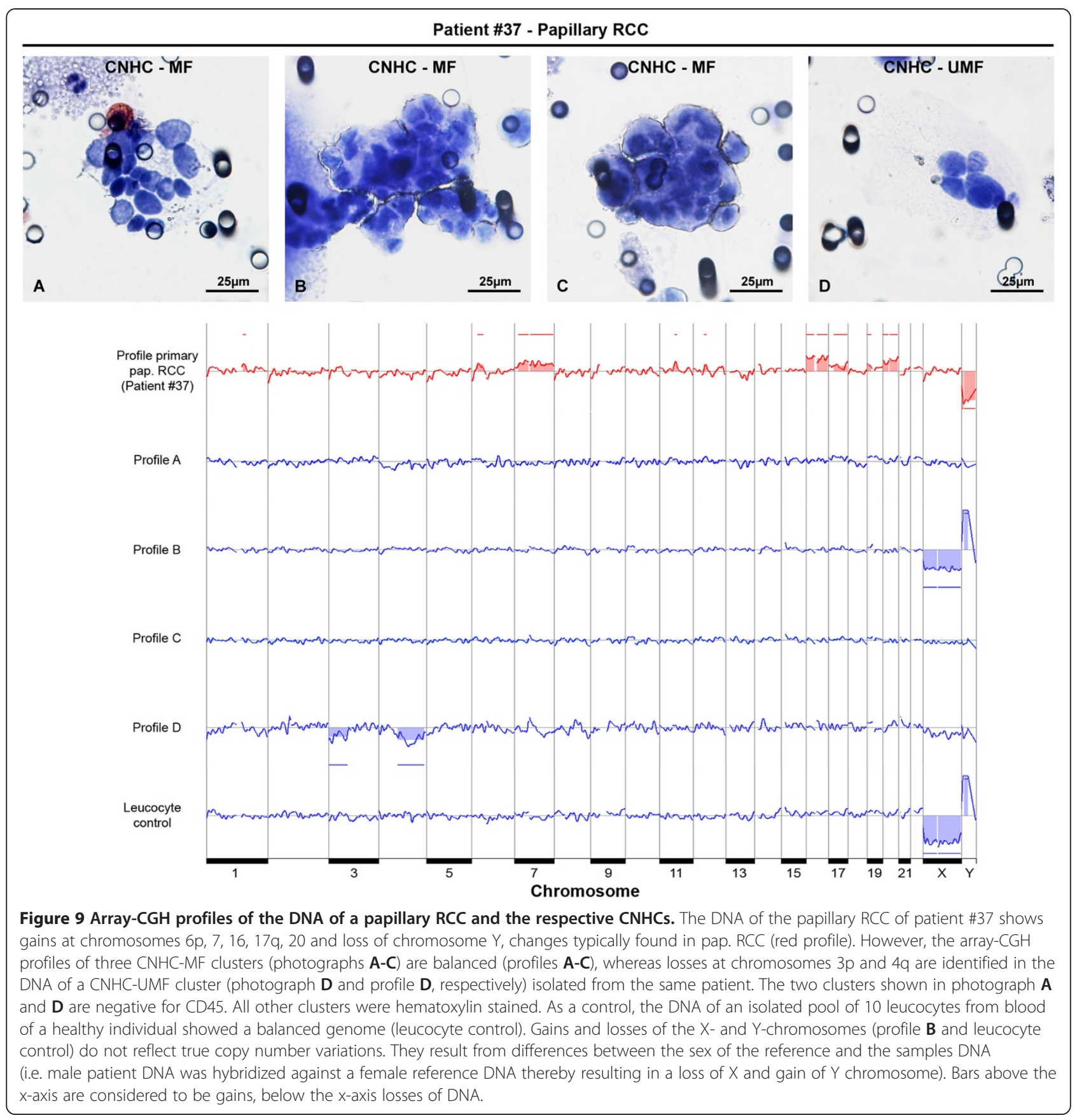

process [39]. Several WGA methods are available to generate sufficient quantities of DNA for array-CGH, all of which are prone to amplification bias [40-42]. We therefore used the GenomePlex library technology which has been shown to exhibit no nucleotide related amplification bias $[43,44]$. In addition, the reference DNA was also amplified using GenomePlex library technology to further minimize the amplification bias [45]. Array-CGH profiles from amplified DNA of few cells tend to be "noisier" than compared to non-amplified DNA [39,43]. Although higher resolutions are reported with dense array platforms [43], copy number variations as small as $6.8 \mathrm{Mb}$ could be identified in our study which seems appropriate to detect large scale aberrations described in RCC [31].

CTMs have been described in several CTC isolation procedures $[19,46,47]$, in particular with techniques relying on size filtration $[11,17,20]$. Based on their cytological features some were designated "atypical", "uncertain malignant" or "morphologically doubtful" $[17,48,49]$. However, endothelial cells, megakaryocytes as well as large monocytes may be difficult to distinguish from "true" CTC or CTM [17]. The reason why circulating benign 


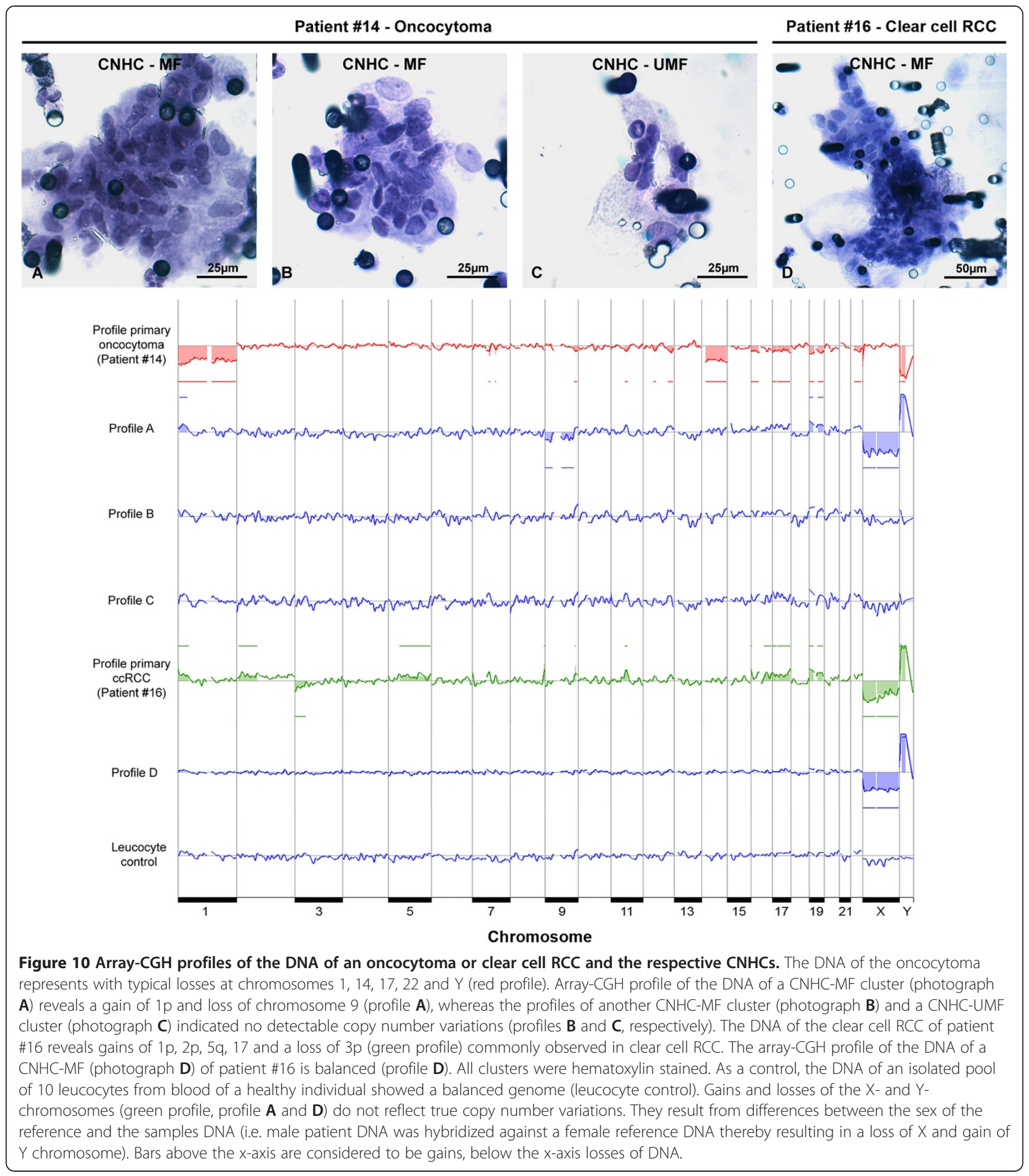

cells display cytological atypia is not known. Reactive changes might be introduced by shear forces in circulation and/or during filtration.

In some studies the $\mathrm{ScreenCell}^{\circ}$ filtration technique was applied to isolate CTC/CTM from the blood of patients with adrenocortical, prostate, colon and breast cancer or malignant melanoma [15,50,51]. These cells have been characterized by immunocytochemistry or telomeric analysis. However, array-CGH data or results from immunocytochemical testing with CD31 antibodies have not been reported. Here we describe for the first time array-CGH analysis of $\mathrm{CNHC}$ clusters cytomorphologically 
Table 4 Summary of the results of array-CGH profiling of the DNA of primary tumors and respective CNHCs

\begin{tabular}{|c|c|c|c|}
\hline \multirow[b]{2}{*}{$\begin{array}{l}\text { Patient } \\
\text { number }\end{array}$} & \multirow[b]{2}{*}{$\begin{array}{l}\text { Items analysed } \\
\text { by array-CGH }\end{array}$} & \multicolumn{2}{|c|}{$\begin{array}{l}\text { Chromosomal aberrations } \\
\text { identified by array-CGH }\end{array}$} \\
\hline & & Gains & Losses \\
\hline \multirow[t]{4}{*}{14} & Oncocytoma & None detected & $1,14,17,22, Y$ \\
\hline & CNHC-MF (A) & $1 p$ & 9 \\
\hline & CNHC-MF (B) & Balanced & Balanced \\
\hline & CNHF-UMF (C) & Balanced & Balanced \\
\hline \multirow[t]{2}{*}{16} & Clear cell RCC & $1 p, 2 p, 5 q, 17$ & $3 p$ \\
\hline & CNHC-MF (D) & Balanced & Balanced \\
\hline \multirow[t]{3}{*}{18} & Cystic nephroma & Not analysed* & Not analysed* \\
\hline & CNHC-UMF $(C)^{* *}$ & Balanced & Balanced \\
\hline & CNHC-UMF $(\mathrm{D})^{* *}$ & Balanced & Balanced \\
\hline \multirow[t]{3}{*}{30} & Clear cell RCC ${ }^{* *}$ & $5 q, 7$ & $3 p$ \\
\hline & CNHC-UMF $(A)^{* *}$ & Balanced & Balanced \\
\hline & CNHC-UMF $(B)^{* *}$ & Balanced & Balanced \\
\hline \multirow[t]{5}{*}{37} & Papillary RCC & $6 p, 7,16,17 q, 20$ & Y \\
\hline & CNHC-MF (A) & Balanced & Balanced \\
\hline & CNHC-MF (B) & Balanced & Balanced \\
\hline & CNHC-MF (C) & Balanced & Balanced \\
\hline & CNHC-UMF (D) & None detected & $3 p, 4 q$ \\
\hline
\end{tabular}

* Unfortunately the quality of the DNA generated from the tumor tissue was not suitable for array-CGH due to insufficient quality.

** Array-CGH profiles are available as additional information (Additional file 5: Figure S1).

resembling CTMs. Array-CGH analysis revealed that the majority of the clusters of the CNHC-MF as well as the CNHC-UMF types did not show chromosomal aberrations and had a balanced genome. The DNA of one CNHCUMF cluster isolated from a patient with pap. RCC and one CNHC-MF cluster from a patient with oncocytoma showed distinct chromosomal abnormalities on arrayCGH which, however, did not match the aberrations found in the respective primary tumors (Figures 9 and 10, respectively) nor in a copy number aberration database (www.progenetix.net) [34]. It might be speculated that these $\mathrm{CNHC}$ clusters represent true CTMs. The reason for the differences of the chromosomal aberrations in the $\mathrm{CNHCs}$ and the respective tumors is not known, however, tumor heterogeneity [52] might be one of the factors responsible.

Data from animal models and patients with nonsmall-cell lung cancer indicate that cellular aggregates in blood may consist of CTCs associated with nonneoplastic cells like stromal cells which could enhance CTC survival and the metastatic process [23,53]. It has been estimated that array-CGH can detect gains and losses in mixed populations of tumor and non-neoplastic cells, if more than $20-25 \%$ of the population consist of tumor cells $[54,55]$. Therefore we cannot exclude that the CNHC of -MF or -UMF types without chromosomal aberrations described in our study also contain low numbers of CTCs that were not detectable by array-CGH.

Our results indicate that $\mathrm{CNHC}$ can be isolated from blood of patients with renal tumors using the ScreenCell ${ }^{\circ}$ system. The majority of the isolated clusters may be of endothelial origin as indicated by positive staining with CD31 antibodies. These putative endothelial cell aggregates have hitherto not been reported in patients with renal tumors. It might be speculated that they mirror active angiogenesis in the tumors or during wound healing after surgery [56]. Increased numbers of CECs, probably shed from activated or damaged tumor vessel walls $[57,58]$ and circulating endothelial progenitor cells derived from the bone marrow have been described in the blood of cancer patients and may importantly contribute to cancer growth and metastasis (reviewed in [58-60]). CECs are also found in several other clinical syndromes with vascular injury as well as in response to chemotherapy and antiangiogenic treatment [61,62]. Therefore CECs and/or endothelial progenitor cells are considered biomarkers of vascular damage. Recently published data suggest CECs as prognostic [63] as well as predictive markers for response to anti-angiogenic therapy in prostate [64] and metastatic renal cell cancer [65-67]. However, their application as biomarkers in clinical practice has been limited by the difficulty to reliably detect them by flow cytometry [68]. Although limited by the relatively small number of cases analysed, the results of our study might indicate that detection of CECs may be facilitated by filtration based and immunocytochemical augmented methods. In this respect it is interesting that we detected a significant increase of the percentage of blood samples positive for all types of $\mathrm{CNHCs}$ one day after surgery as compared during surgery. This was also found for CNHC-UMF and -BF-positive samples, but not CNHC-MF-containing samples eight days after surgery.

\section{Conclusions}

For patients with renal tumors cytomorphological classification alone seems not to be sufficient to allow for reliable distinction of epithelial CNHCs - the putative CTCs or CTMs - from endothelial CNHCs. As also suggested by others, reliable detection of CTCs or CTMs should thus be confirmed by immunocytochemical and/or molecular biological methods $[17,69]$.

\section{Additional files}

Additional file 1: Movie 1. An exemplary laser capture microdissection. Additional file 2: Table S1. Correlation of tumor size and number of CNHCS. 
Additional file 3: Table S2. Relationship of tumor grade and number of CNHCS.

Additional file 4: Table S3. Relationship of venous invasion and number of $\mathrm{CNHCS}$

Additional file 5: Figure S1. Array-CGH profiles of the DNA of a clear cell RCC and the respective CNHCs or CNHCs derived from a patient with a cystic nephroma. The DNA of the clear cell RCC of patient \#30 reveals gains of $5 q, 7$ and losses of $3 p$, changes commonly observed in clear cell RCC (red profile). The array-CGH profile of the DNA of two CNHC-UMF clusters (photograph A and B) of patient \#30 represent with balanced genomes (profile $\mathrm{A}$ and $\mathrm{B}$ ). The array-CGH profile of the two CNHC-UMF clusters (photograph $C$ and $D$ ) revealed balanced genomes (profile $C$ and D). All clusters were hematoxylin stained. The DNA of the respective renal tissue was not suited for array-CGH analysis due to insufficient quality. Gains and losses of the $X$ - and $Y$-chromosomes do not reflect true copy number variations. They result from differences between the sex of the reference and the samples DNA (i.e. male patient DNA was hybridized against a female reference DNA thereby resulting in a loss of $X$ and gain of $Y$ chromosome and vice versa). Bars above the $X$-axis are considered to be gains, below the $x$-axis losses of DNA.

\section{Competing interests}

The authors declare that they have no competing interests.

\section{Authors' contributions}

$\mathrm{CL}, \mathrm{PS}, \mathrm{RZ}$, and $\mathrm{BH}$ designed the study. Data was collected and assembled by $A E, T K, E Z, J H$ and $C L$. The interpretation and analysis was performed by $A E$, $\mathrm{TK}, \mathrm{CL}, \mathrm{PS}, \mathrm{BH}, \mathrm{JBG}, \mathrm{RR}, \mathrm{JH}$. The samples and patient data were retrieved by KF, KKK, RZ, HP and RS. The manuscript was drafted by $A E, C L, P S$. All authors read and approved the final manuscript.

\section{Acknowledgements}

The authors wish to thank Ralph Koenig for his help with the graphical design of the figures, Martina Auer, Eva Maria Hoffman and Daniel Kummer for their technical advice. The tissue samples used in this project have been provided by Biobank Graz.

\section{Author details \\ ${ }^{1}$ Institute of Cell Biology, Histology \& Embryology, Medical University of Graz, Harrachgasse 21/II, $8010 \mathrm{Graz}$, Austria. ${ }^{2}$ Institute of Pathology, Medical University of Graz, Auenbruggerplatz 25, 8036 Graz, Austria. ${ }^{3}$ Department of Urology, Medical University of Graz, Auenbruggerplatz 5/6, 8036 Graz, Austria. ${ }^{4}$ Department of Internal Medicine, Division of Gastroenterology and Hepatology, Medical University of Graz, Auenbruggerplatz 15, 8036 Graz, Austria. ${ }^{5}$ Institute for Medical Informatics, Statistics and Documentation, Medical University of Graz, Auenbruggerplatz 2, 8036 Graz, Austria. ${ }^{6}$ Institute of Human Genetics, Medical University of Graz, Harrachgasse 21 NIII, 8010 Graz, Austria.}

Received: 24 May 2013 Accepted: 13 September 2013 Published: 17 September 2013

\section{References}

1. Paterlini-Brechot $P$, Benali NL: Circulating tumor cells (CTC) detection: clinical impact and future directions. Cancer Lett 2007, 253:180-204.

2. Zhao S, Liu Y, Zhang Q, Li H, Zhang M, Ma W, Zhao W, Wang J, Yang M: The prognostic role of circulating tumor cells (CTCS) detected by RT-PCR in breast cancer: a meta-analysis of published literature. Breast Cancer Res Treat 2011, 130:809-816.

3. Rahbari NN, Aigner M, Thorlund K, Mollberg N, Motschall E, Jensen K, Diener MK, Buchler MW, Koch M, Weitz J: Meta-analysis shows that detection of circulating tumor cells indicates poor prognosis in patients with colorectal cancer. Gastroenterology 2010, 138:1714-1726.

4. De Albuquerque A, Kubisch I, Stolzel U, Ernst D, Boese-Landgraf J, Breier G Stamminger G, Fersis N, Kaul S: Prognostic and predictive value of circulating tumor cell analysis in colorectal cancer patients. J Trans/ Med 2012, 10:222-5876-10-222.

5. Pichler M, Hutterer GC, Chromecki TF, Jesche J, Kampel-Kettner K, Rehak P, Pummer K, Zigeuner R: External validation of the Leibovich prognosis score for nonmetastatic clear cell renal cell carcinoma at a single European center applying routine pathology. J Urol 2011, 186:1773-1777.

6. Escudier B, Eisen T, Stadler WM, Szczylik C, Oudard S, Staehler M, Negrier S, Chevreau C, Desai AA, Rolland F, Demkow T, Hutson TE, Gore M, Anderson S, Hofilena G, Shan M, Pena C, Lathia C, Bukowski RM: Sorafenib for treatment of renal cell carcinoma: final efficacy and safety results of the phase III treatment approaches in renal cancer global evaluation trial. $J$ Clin Oncol 2009, 27:3312-3318.

7. Motzer RJ, Hutson TE, Tomczak P, Michaelson MD, Bukowski RM, Oudard S, Negrier S, Szczylik C, Pili R, Bjarnason GA, Garcia-del-Muro X, Sosman JA, Solska E, Wilding G, Thompson JA, Kim ST, Chen I, Huang X, Figlin RA: Overall survival and updated results for sunitinib compared with interferon alfa in patients with metastatic renal cell carcinoma. J Clin Oncol 2009, 27:3584-3590.

8. Small AC, Gong Y, Oh WK, Hall SJ, van Rijn CJ, Galsky MD: The emerging role of circulating tumor cell detection in genitourinary cancer. $J$ Urol 2012, 188:21-26.

9. Parkinson DR, Dracopoli N, Petty BG, Compton C, Cristofanilli M, Deisseroth A Hayes DF, Kapke G, Kumar P, Lee JS, Liu MC, McCormack R, Mikulski S, Nagahara L, Pantel K, Pearson-White S, Punnoose EA, Roadcap LT, Schade AE, Scher HI, Sigman CC, Kelloff GJ: Considerations in the development of circulating tumor cell technology for clinical use. J Trans/ Med 2012, 10:138-5876-10-138

10. Christiansen JJ, Rajasekaran AK: Reassessing epithelial to mesenchymal transition as a prerequisite for carcinoma invasion and metastasis. Cancer Res 2006, 66:8319-8326.

11. Krebs MG, Hou JM, Sloane R, Lancashire L, Priest L, Nonaka D, Ward TH, Backen A, Clack G, Hughes A, Ranson M, Blackhall FH, Dive C: Analysis of circulating tumor cells in patients with non-small cell lung cancer using epithelial marker-dependent and -independent approaches. J Thorac Oncol 2012, 7:306-315.

12. Raimondi C, Gradilone A, Naso G, Vincenzi B, Petracca A, Nicolazzo C, Palazzo A, Saltarelli R, Spremberg F, Cortesi E, Gazzaniga P: Epithelialmesenchymal transition and stemness features in circulating tumor cells from breast cancer patients. Breast Cancer Res Treat 2011, 130:449-455.

13. Joosse SA, Pantel K: Biologic challenges in the detection of circulating tumor cells. Cancer Res 2013, 73:8-11.

14. Zheng S, Lin HK, Lu B, Williams A, Datar R, Cote RJ, Tai YC: 3D microfilter device for viable circulating tumor cell (CTC) enrichment from blood. Biomed Microdevices 2011, 13:203-213.

15. Desitter I, Guerrouahen BS, Benali-Furet N, Wechsler J, Janne PA, Kuang Y, Yanagita M, Wang L, Berkowitz JA, Distel RJ, Cayre YE: A new device for rapid isolation by size and characterization of rare circulating tumor cells. Anticancer Res 2011, 31:427-441

16. Vona G, Sabile A, Louha M, Sitruk V, Romana S, Schutze K, Capron F, Franco D, Pazzagli M, Vekemans M, Lacour B, Brechot C, Paterlini-Brechot P: Isolation by size of epithelial tumor cells : a new method for the immunomorphological and molecular characterization of circulatingtumor cells. Am J Pathol 2000, 156:57-63.

17. Hofman VJ, llie MI, Bonnetaud C, Selva E, Long E, Molina T, Vignaud JM, Flejou JF, Lantuejoul S, Piaton E, Butori C, Mourad N, Poudenx M, Bahadoran P, Sibon S, Guevara N, Santini J, Venissac N, Mouroux J, Vielh P, Hofman PM: Cytopathologic detection of circulating tumor cells using the isolation by size of epithelial tumor cell method: promises and pitfalls. Am J Clin Pathol 2011, 135:146-156.

18. Hofman V, Bonnetaud C, Ilie MI, Vielh P, Vignaud JM, Flejou JF, Lantuejoul S, Piaton E, Mourad N, Butori C, Selva E, Poudenx M, Sibon S, Kelhef S, Venissac N, Jais JP, Mouroux J, Molina TJ, Hofman P: Preoperative circulating tumor cell detection using the isolation by size of epithelial tumor cell method for patients with lung cancer is a new prognostic biomarker. Clin Cancer Res 2011, 17:827-835.

19. Hou JM, Krebs MG, Lancashire L, Sloane R, Backen A, Swain RK, Priest LJ, Greystoke A, Zhou C, Morris K, Ward T, Blackhall FH, Dive C: Clinical significance and molecular characteristics of circulating tumor cells and circulating tumor microemboli in patients with small-cell lung cancer. J Clin Oncol 2012, 30:525-532.

20. Khoja L, Backen A, Sloane R, Menasce L, Ryder D, Krebs M, Board R, Clack G, Hughes A, Blackhall F, Valle JW, Dive C: A pilot study to explore circulating tumour cells in pancreatic cancer as a novel biomarker. Br J Cancer 2012, 106:508-516.

21. Pinzani P, Salvadori B, Simi L, Bianchi S, Distante V, Cataliotti L, Pazzagli M, Orlando C: Isolation by size of epithelial tumor cells in peripheral blood 
of patients with breast cancer: correlation with real-time reverse transcriptase-polymerase chain reaction results and feasibility of molecular analysis by laser microdissection. Hum Pathol 2006, 37:711-718.

22. Vona G, Estepa L, Beroud C, Damotte D, Capron F, Nalpas B, Mineur A, Franco D, Lacour B, Pol S, Brechot C, Paterlini-Brechot P: Impact of cytomorphological detection of circulating tumor cells in patients with liver cancer. Hepatology 2004, 39:792-797.

23. Pailler E, Adam J, Barthelemy A, Oulhen M, Auger N, Valent A, Borget I, Planchard D, Taylor M, Andre F, Soria JC, Vielh P, Besse B, Farace F: Detection of circulating tumor cells harboring a unique ALK rearrangement in ALK-positive Non-small-cell lung cancer. J Clin Oncol 2013, 31:2273-2281.

24. Sobin LH, Gospodarowicz MK, Wittekind C: TNM Classification of Malignant Tumours (Uicc International Union Against Cancer). 7th edition. Hoboken, NJ USA: John Wiley \& Sons; 2009

25. van Beers EH, Joosse SA, Ligtenberg MJ, Fles R, Hogervorst FB, Verhoef S, Nederlof PM: A multiplex PCR predictor for aCGH success of FFPE samples. Br J Cancer 2006, 94:333-337.

26. Liu L, Qian J, Singh H, Meiers I, Zhou X, Bostwick DG: Immunohistochemical analysis of chromophobe renal cell carcinoma, renal oncocytoma, and clear cell carcinoma: an optimal and practical panel for differential diagnosis. Arch Pathol Lab Med 2007, 131:1290-1297.

27. Gupta R, Balzer B, Picken M, Osunkoya AO, Shet T, Alsabeh R, Luthringer D, Paner GP, Amin MB: Diagnostic implications of transcription factor Pax 2 protein and transmembrane enzyme complex carbonic anhydrase IX immunoreactivity in adult renal epithelial neoplasms. Am J Surg Pathol 2009, 33:241-247.

28. Ivanov S, Liao SY, Ivanova A, Danilkovitch-Miagkova A, Tarasova N, Weirich G, Merrill MJ, Proescholdt MA, Oldfield EH, Lee J, Zavada J, Waheed A, Sly W, Lerman MI, Stanbridge EJ: Expression of hypoxia-inducible cell-surface transmembrane carbonic anhydrases in human cancer. Am J Pathol 2001, 158:905-919.

29. Geigl JB, Speicher MR: Single-cell isolation from cell suspensions and whole genome amplification from single cells to provide templates for CGH analysis. Nat Protoc 2007, 2:3173-3184.

30. Fiegler H, Carr P, Douglas EJ, Burford DC, Hunt S, Scott CE, Smith J, Vetrie D, Gorman P, Tomlinson IP, Carter NP: DNA microarrays for comparative genomic hybridization based on DOP-PCR amplification of BAC and PAC clones. Genes Chromosomes Cancer 2003, 36:361-374

31. Klatte T, Rao PN, de Martino M, LaRochelle J, Shuch B, Zomorodian N, Said J, Kabbinavar FF, Belldegrun AS, Pantuck AJ: Cytogenetic profile predicts prognosis of patients with clear cell renal cell carcinoma. J Clin Oncol 2009, 27:746-753.

32. Brunelli M, Eble JN, Zhang S, Martignoni G, Cheng L: Gains of chromosomes $7,17,12,16$, and 20 and loss of $Y$ occur early in the evolution of papillary renal cell neoplasia: a fluorescent in situ hybridization study. Mod Pathol 2003, 16:1053-1059.

33. Presti JC Jr, Moch H, Reuter VE, Huynh D, Waldman FM: Comparative genomic hybridization for genetic analysis of renal oncocytomas. Genes Chromosomes Cancer 1996, 17:199-204.

34. Baudis M, Cleary ML: Progenetix.net: an online repository for molecular cytogenetic aberration data. Bioinformatics 2001, 17:1228-1229.

35. Thomas ML: The leukocyte common antigen family. Annu Rev Immunol 1989, 7:339-369.

36. Dorai T, Sawczuk IS, Pastorek J, Wiernik PH, Dutcher JP: The role of carbonic anhydrase IX overexpression in kidney cancer. Eur J Cancer 2005, 41:2935-2947.

37. Grabmaier K, A de Weijert MC, Verhaegh GW, Schalken JA, Oosterwijk E: Strict regulation of CAIX(G250/MN) by HIF-1alpha in clear cell renal cell carcinoma. Oncogene 2004, 23:5624-5631.

38. Parums DV, Cordell JL, Micklem K, Heryet AR, Gatter KC, Mason DY: JC70: a new monoclonal antibody that detects vascular endothelium associated antigen on routinely processed tissue sections. J Clin Pathol 1990, 43:752-757.

39. Mathiesen RR, Fjelldal R, Liestol K, Due EU, Geigl JB, Riethdorf S, Borgen E, Rye $I_{H}$, Schneider IJ, Obenauf AC, Mauermann O, Nilsen G, Christian Lingjaerde O, Borresen-Dale AL, Pantel K, Speicher MR, Naume B, Baumbusch LO: High-resolution analyses of copy number changes in disseminated tumor cells of patients with breast cancer. Int J Cancer 2012, 131:E405-E415.

40. Hou $Y$, Song $L$, Zhu P, Zhang B, Tao Y, Xu X, Li F, Wu K, Liang J, Shao D, Wu $H$, Ye X, Ye C, Wu R, Jian M, Chen Y, Xie W, Zhang R, Chen L, Liu X, Yao X,
Zheng H, Yu C, Li Q, Gong Z, Mao M, Yang X, Yang L, Li J, Wang W, et al: Single-cell exome sequencing and monoclonal evolution of a JAK2negative myeloproliferative neoplasm. Cell 2012, 148:873-885.

41. Hu DG, Webb G, Hussey N: Aneuploidy detection in single cells using DNA array-based comparative genomic hybridization. Mol Hum Reprod 2004, 10:283-289.

42. Fuhrmann C, Schmidt-Kittler O, Stoecklein NH, Petat-Dutter K, Vay C, Bockler K Reinhardt R, Ragg T, Klein CA: High-resolution array comparative genomic hybridization of single micrometastatic tumor cells. Nucleic Acids Res 2008, 36:e39.

43. Geigl JB, Obenauf AC, Waldispuehl-Geigl J, Hoffmann EM, Auer M, Hormann M, Fischer M, Trajanoski Z, Schenk MA, Baumbusch LO, Speicher MR: Identification of small gains and losses in single cells after whole genome amplification on tiling oligo arrays. Nucleic Acids Res 2009, 37:e105.

44. Fiegler H, Geigl JB, Langer S, Rigler D, Porter K, Unger K, Carter NP, Speicher MR: High resolution array-CGH analysis of single cells. Nucleic Acids Res 2007, 35:e15.

45. Pugh TJ, Delaney AD, Farnoud N, Flibotte S, Griffith M, Li HI, Qian H, Farinha P, Gascoyne RD, Marra MA: Impact of whole genome amplification on analysis of copy number variants. Nucleic Acids Res 2008, 36:e80.

46. Molnar B, Ladanyi A, Tanko L, Sreter L, Tulassay Z: Circulating tumor cell clusters in the peripheral blood of colorectal cancer patients. Clin Cancer Res 2001, 7:4080-4085

47. Stott SL, Hsu CH, Tsukrov DI, Yu M, Miyamoto DT, Waltman BA, Rothenberg SM, Shah AM, Smas ME, Korir GK, Floyd FP Jr, Gilman AJ, Lord JB, Winokur D, Springer S, Irimia D, Nagrath S, Sequist LV, Lee RJ, Isselbacher KJ, Maheswaran S, Haber DA, Toner M: Isolation of circulating tumor cells using a microvortex-generating herringbone-chip. Proc Natl Acad Sci U S A 2010, 107:18392-18397.

48. Farace F, Massard C, Vimond N, Drusch F, Jacques N, Billiot F, Laplanche A, Chauchereau A, Lacroix L, Planchard D, Le Moulec S, Andre F, Fizazi K, Soria JC, Vielh P: A direct comparison of Cell Search and ISET for circulating tumour-cell detection in patients with metastatic carcinomas. Br J Cancer 2011, 105:847-853.

49. De Giorgi V, Pinzani P, Salvianti F, Panelos J, Paglierani M, Janowska A, Grazzini M, Wechsler J, Orlando C, Santucci M, Lotti T, Pazzagli M, Massi D: Application of a filtration- and isolation-by-size technique for the detection of circulating tumor cells in cutaneous melanoma. J Invest Dermatol 2010, 130:2440-2447.

50. Pinzani P, Scatena C, Salvianti F, Corsini E, Canu L, Poli G, Paglierani M Piccini V, Pazzagli M, Nesi G, Mannelli M, Luconi M: Detection of circulating tumor cells in patients with adrenocortical carcinoma: a monocentric preliminary study. J Clin Endocrinol Metab 2013, 98:3731-3738.

51. Adebayo Awe J, Xu MC, Wechsler J, Benali-Furet N, Cayre YE, Saranchuk J, Drachenberg D, Mai S: Three-dimensional telomeric analysis of isolated circulating tumor cells (CTCs) defines CTC subpopulations. Trans/ Oncol 2013, 6:51-65.

52. Gerlinger M, Rowan AJ, Horswell S, Larkin J, Endesfelder D, Gronroos E, Martinez P, Matthews N, Stewart A, Tarpey P, Varela I, Phillimore B, Begum S, McDonald NQ, Butler A, Jones D, Raine K, Latimer C, Santos CR, Nohadani M, Eklund AC, Spencer-Dene B, Clark G, Pickering L, Stamp G, Gore M, Szallasi Z, Downward J, Futreal PA, Swanton C: Intratumor heterogeneity and branched evolution revealed by multiregion sequencing. N Engl J Med 2012, 366:883-892.

53. Duda DG, Duyverman AM, Kohno M, Snuderl M, Steller EJ, Fukumura D, Jain RK: Malignant cells facilitate lung metastasis by bringing their own soil. Proc Natl Acad Sci U S A 2010, 107:21677-21682.

54. Ballif BC, Rorem EA, Sundin K, Lincicum M, Gaskin S, Coppinger J, Kashork CD, Shaffer LG, Bejjani BA: Detection of low-level mosaicism by array CGH in routine diagnostic specimens. Am J Med Genet A 2006, 140:2757-2767.

55. Patel A, Kang SH, Lennon PA, Li YF, Rao PN, Abruzzo L, Shaw C, Chinault AC, Cheung SW: Validation of a targeted DNA microarray for the clinical evaluation of recurrent abnormalities in chronic lymphocytic leukemia. Am J Hematol 2008, 83:540-546.

56. Park $Y$, Kitahara $T$, Takagi $R$, Kato R: Does surgery for breast cancer induce angiogenesis and thus promote metastasis? Oncology 2011, 81:199-205.

57. Chang YS, di Tomaso E, McDonald DM, Jones R, Jain RK, Munn LL: Mosaic blood vessels in tumors: frequency of cancer cells in contact with flowing blood. Proc Natl Acad Sci U S A 2000, 97:14608-14613.

58. Mancuso P, Calleri A, Bertolini F: Circulating endothelial cells and circulating endothelial progenitors. Recent Results Cancer Res 2012, 195:163-170. 
59. Ribatti D, Ranieri G, Basile A, Azzariti A, Paradiso A, Vacca A: Tumor endothelial markers as a target in cancer. Expert Opin Ther Targets 2012, 16:1215-1225.

60. Strijbos MH: Circulating tumour cells and circulating endothelial cells as biomarkers in oncology. Acta Clin Belg 2011, 66:332-336.

61. Shaked Y, Ciarrocchi A, Franco M, Lee CR, Man S, Cheung AM, Hicklin DJ, Chaplin D, Foster FS, Benezra R, Kerbel RS: Therapy-induced acute recruitment of circulating endothelial progenitor cells to tumors. Science 2006, 313:1785-1787.

62. Shaked $Y$, Henke E, Roodhart JM, Mancuso P, Langenberg MH, Colleoni M, Daenen LG, Man S, Xu P, Emmenegger U, Tang T, Zhu Z, Witte L, Strieter RM, Bertolini F, Voest EE, Benezra R, Kerbel RS: Rapid chemotherapyinduced acute endothelial progenitor cell mobilization: implications for antiangiogenic drugs as chemosensitizing agents. Cancer Cell 2008, 14:263-273.

63. Strijbos MH, Gratama JW, Schmitz PI, Rao C, Onstenk W, Doyle GV, Miller MC, de Wit R, Terstappen LW, Sleijfer S: Circulating endothelial cells, circulating tumour cells, tissue factor, endothelin-1 and overall survival in prostate cancer patients treated with docetaxel. Eur J Cancer 2010, 46:2027-2035.

64. Matsusaka S, Suenaga M, Mishima Y, Takagi K, Terui Y, Mizunuma N, Hatake K: Circulating endothelial cells predict for response to bevacizumab-based chemotherapy in metastatic colorectal cancer. Cancer Chemother Pharmacol 2011, 68:763-768.

65. Gruenwald V, Beutel G, Schuch-Jantsch S, Reuter C, Ivanyi P, Ganser A, Haubitz M: Circulating endothelial cells are an early predictor in renal cell carcinoma for tumor response to sunitinib. BMC Cancer 2010, 10:695.

66. Mancuso A, Di Paola ED, Leone A, Catalano A, Calabro F, Cerbone L, Zivi A, Messina C, Alonso S, Vigna L, Caristo R, Sternberg CN: Phase II escalation study of sorafenib in patients with metastatic renal cell carcinoma who have been previously treated with anti-angiogenic treatment. BJU Int 2012, 109:200-206.

67. Vroling L, van der Veldt AA, de Haas RR, Haanen JB, Schuurhuis GJ, Kuik DJ, van Cruijsen $H$, Verheul HM, van den Eertwegh AJ, Hoekman K, Boven E, van Hinsbergh WW, Broxterman $\mathrm{HJ}$ : Increased numbers of small circulating endothelial cells in renal cell cancer patients treated with sunitinib. Angiogenesis 2009, 12:69-79.

68. Hernandez-Yanez M, Heymach JV, Zurita AJ: Circulating biomarkers in advanced renal cell carcinoma: clinical applications. Curr Oncol Rep 2012, 14:221-229.

69. Pantel K, Deneve E, Nocca D, Coffy A, Vendrell JP, Maudelonde T, Riethdorf S, Alix-Panabieres C: Circulating epithelial cells in patients with benign colon diseases. Clin Chem 2012, 58:936-940.

doi:10.1186/1479-5876-11-214

Cite this article as: El-Heliebi et al:: Are morphological criteria sufficient for the identification of circulating tumor cells in renal cancer?. Journal of Translational Medicine 2013 11:214.

\section{Submit your next manuscript to BioMed Central and take full advantage of:}

- Convenient online submission

- Thorough peer review

- No space constraints or color figure charges

- Immediate publication on acceptance

- Inclusion in PubMed, CAS, Scopus and Google Scholar

- Research which is freely available for redistribution

Submit your manuscript at www.biomedcentral.com/submit
C Biomed Central 